\title{
CCAMLR and Southern Ocean Fisheries
}

\author{
Erik Jaap Molenaar* \\ Netherlands Institute for the Law of the Sea (NILOS). \\ Utrecht University
}

\begin{abstract}
The Convention on the Conservation of Antarctic Marine Living Resources (CCAMLR Convention) forms the core of the regulatory regime for Southern Ocean fisheries. This article analyses the scope and extent of the Convention and the competence of the bodies established under it while also addressing the role of states and other international intergovernmental organisations with relevant competence. As part of the Anlarctic Treaty System (ATS), the CCAMLR Convention is characterised by a unique sovereignty situation. The analysis thereof is complemented by a comparison with (other) regional fisheries management organisations (RFMOs) and illustrated by the difficulties in addressing illegal, unreported and unregulated (IUU) fishing. The article concludes inter alia that the CCAMLR Convention is unlike other RFMOs due to the special natural characteristics, its integration into the ATS and the ensuing sovereignty situation, and its conservationist objective. This notwithstanding, it seems justifiable to treat the CCAMLR Convention as "something more" than an RFMO for the purpose of international instruments on fisheries.
\end{abstract}

\section{Introduction}

Fishing in the Southern Ocean is a commercial activity unlike any other. The extreme sea and weather circumstances and the long periods out at sea will undoubtedly make any captain and crew seriously consider alternative fisheries or occupations. The revenues derived from the two main target species, namely Patagonian and Antarctic toothfish (Dissostichus eleginoides and Dissostichus mawsoni) (hereinafter toothfish) and krill (Euphasia superba), ${ }^{1}$ must therefore be

* The author would like to acknowledge the generous assistance of, and/or comments by, $\mathrm{M}$. Bliss, C. Le-Villain, D. Miller and F. Wong on an earlier version of this article. The author naturally remains responsible for the current text. A somewhat different and shorter version of this article will appear in D.R. Rothwell and A.G. Oude Elferink (eds), The Law of the Sea and Polar Maritime Delimitation and Jurisdiction, which will be published by Kluwer Law International in 2001. The author is grateful to the editors and Kluwer Law International for their permission to draw on this work. The information on the internet referred to in this article was available at 19 April 2001.

THE INTERNATIONAL JOURNAL OF MARINE AND COASTAL LAW, Vol 16, No 3

(C) Kluwer Law International, 2001 
worthwhile. While toothfish is renowned for its good taste, krill is processed for aquaculture feed and bait and, besides human consumption, also has potential for biochemical products.

Exploitation in the Southern Ocean has followed a pattern of "discovery, fullscale exploitation and rapid depletion, followed by a switch to other stocks or species". 2 Like other finfish species in the Southern Ocean, toothfish is vulnerable due to its slow growth and low productivity. It has only been really targeted since the mid-1980s but in recent years it has come under enormous pressure, in particular through illegal, unreported and unregulated (IUU) fishing. ${ }^{3}$ Chances are that the "boom and bust" cycle will therefore be repeated. The krill fishery is currently not over-exploited but this appears to be mainly caused by economic factors. The fact that a survey carried out in 2000 revised previous biomass estimates substantially upwards, allowing for considerable catch increases, may therefore not necessarily lead to a booming krill fishery. ${ }^{4}$

In this article, the term "Southern Ocean fisheries" refers to fishing activity in the ocean areas within the confines of the CCAMLR Convention ${ }^{5}$ Area. The focus of discussion will be primarily on the efforts undertaken within the framework of the CCAMLR Convention, but attention is also given to the states and international intergovernmental organisations with relevant competence, both substantively and geographically, and both within and adjacent to the CCAMLR Convention Area. The comprehensive and integrated approach needed for sustainable management of marine living resources warrants this. ${ }^{6}$ The special sovereignty situation in Antarctica will obviously assume a prominent role. In that context, this article will examine the extent to which the CCAMLR Convention is distinguishable from (other) regional fisheries management organisations (RFMOs).

Discussion will start with certain general aspects of the CCAMLR Convention, such as conservation objectives, institutional bodies, the CCAMLR

1 Other target species are various other species of finfish, squid and crab.

2 "CCAMLR's Management of the Antarctic" in the Introduction section (text at www.ccamlr. org; see also "Understanding CCAMLR's Approach to Management", at the same location, which gives in Annex I a sad account of collapsed fisheries, e.g. marbled rock cod (Notothenia rossii)). For more background information on various aspects of Southern Ocean fisheries, see the ISOFISH (International Southern Oceans Longline Fisheries Information Clearing House) website, www.isofish.org.au.

3 See D.J. Agnew, "The Illegal and Unregulated Fishery for Toothfish in the Southern Ocean, and the CCAMLR Catch Documentation Scheme", (2000) 24 Marine Policy 361-374 at 362.

4 See Doc. CCAMLR-XIX, paras 4.15-4.19 and 10.9 10.14 (advance copy). See nevertheless the concerns expressed by the Antarctic and Southern Ocean Commission (ASOC) in its newspaper $E C O$, at www.asoc.org.

5 Convention on the Conservation of Antarctic Marine Living Resources, Canberra, 20 May 1980, in force 7 April 1982, www.ccamlr.org. The term "CCAMLR Convention" is used to avoid confusion with the Convention's main regulatory body: the "Commission" (see note 10 and accompanying text)

6 The need for this is reaffirmed inter alia in UN General Assembly Resolution A/RES/55/8 (2000), Preamble (after "Welcoming ..."). 
Convention's regulatory area and shared or complementary competence with other RFMOs or international intergovernmental organisations. A separate subsection is devoted to marine mammals. The subsequent section then examines the impact of Antarctic territorial claims and the sub-Antarctic islands on the CCAMLR regime. Subsequently, the next two sections then focus on some selected topics of current relevance: IUU fishing and the proper characterisation of the CCAMLR Convention and the role of the European Community (EC) therein. A final section ends with some conclusions.

\section{General Aspects of the CCAMLR Convention}

\section{Objective and Institutional Bodies}

Article II(1) and (2) of the CCAMLR Convention defines as the Convention's objective the "conservation of Antarctic marine living resources", while "the term "conservation' includes rational use". Paragraph (3) of Article II lists the three principles of conservation that should be observed for harvesting and other activities in the CCAMLR Convention Area. Rather than naming these principles, a detailed description of their meaning and intention has been opted for. Read together, as they should be, they reflect a considerable "conservationist" attitude, in particular due to their adherence to multi-species management and the ecosystem approach. This clearly addresses the concerns that largescale krill harvesting in the Southern Ocean would threaten the entire ecosystem, which was the primary impetus for developing the CCAMLR Convention. ${ }^{7}$ The relatively low biodiversity and few trophic levels in the Southern Ocean made the ecosystem approach a logical choice but also a comparatively feasible one.

Article II(3) does not explicitly use the term "ecosystem approach" or "precautionary approach". The lack of scientific data and the vastness of the regulatory area were nevertheless instrumental in the progressive and pioneering adherence to the latter. ${ }^{8}$ The CCAMLR Convention's objective, conservation

7 See S. Kaye International Fisheries Management (The Hague, London and Boston, Kluwer Law International, 2001), p. 363, who regards the concern for krill and the Antarctic marine ecosystem as a fundamentally different point of departure than the objective of maximum sustainable yield, which is typical for many other [isheries (see pp. 3-4 and 6). An argument not made by Kaye, but by several other authors (e.g. A. Watts, International Law and the Antarctic Treaty System (Cambridge, Grotius Publications Limited, 1992), p. 215) that the CCAMLR Convention is unique because it was developed prior to commercial exploitation, is only correct in relation to krill (see inter alia "Understanding CCAMLR's Approach to Management", note 2 above).

8 G. Parkes, "Precautionary Fisheries Management: The CCAMLR Approach", (2000) 24 Marine Policy 83-91, argues that, even though conservation and management in the CCAMLR regime did not use to refer to the precautionary approach, it was in fact widely taken into account (cf. Kaye, note 7 above at pp. 374 and 411-415). In more recent ycars, however, frequent use is made of this term (e.g. Conservation Measures (CMs) 32/XIX, 45/XIV and 106/ XIX). Particularly reflective of the precautionary approach are CMs $31 / \mathrm{X}$ and $65 / \mathrm{XII}$ on New Fisheries and Exploratory Fisheries respectively. See also Docs CCAMLR-XIX/BG, para. 10 and CCAMLR-XIX, para. 13.7 (advance copy). 
principles and management approaches are ambitious and distinguish it from many other RFMOs, despite the fact that considerable efforts still have to be made and hurdles overcome to ensure their optimum implementation. ${ }^{9}$

Some indication of its "conservationist" character is also that engaging in harvesting (as a flag state) is not a condition that acceding states must meet if they want to become a member of the Commission for the Conservation of Antarctic Marine Living Resources (hereinafter "the Commission"), the Convention's main regulatory body. ${ }^{10}$ The 22 original signatory states, who automatically became members of the Commission, did not have to meet such a condition either and several are also currently not engaged in harvesting. ${ }^{11}$ Very few RFMOs pursue such an approach. ${ }^{12}$ As at 1 December 2000 there were 30 contracting parties to the CCAMLR Convention. Of these, the 22 original signatory states and the EC are members of the Commission,,$^{13}$ while the seven acceding states are currently all non-members. ${ }^{14}$

The Commission is charged with giving effect to the objective and principles set out in Article II. The various ways by which it can perform this mandate are

9 See "Understanding CCAMLR's Approach to Management". note 2 above, in particular section 3 ; and Kaye, note 7 above at pp. 407-424.

10 While accession is open to "any State interested in research or harvesting activities in relation to the marine living resources to which this Convention applies" (Art. XXIX(1)), membership of the Commission is only possible, but not mandatory, "during such time as [the] acceding Party is engaged in research or harvesting activities" etc. (Art. VII(2)(b)). Arguably, the clause "during such time" would not prevent an acceding state from discontinuing research or harvesting activities and still remain a member of the Commission (cf. Watts, note 7 above at p. 43). The practice has at any rate been not to expel such states from the Commission. In case of moratoria on fishing, this would also have an undesirable result.

1 See Arts VII(2)(a) and XXVI(2) of the CCAMLR Convention. The original signatories are: Argentina, Australia, Belgium, Brazil, Chile, France, Germany, India, Italy, Japan, Republic of Korea, New Zealand, Norway, Poland, the Russian Federation, South Africa, Spain, Sweden, Ukraine, the United Kingdom, the United States and Uruguay. Of these, Belgium, Germany, India, Italy and Sweden seem to have no intention to engage in harvesting for the $2000 / 2001$ split-year.

12 An obvious exception is the IWC Convention (Art. X(2); see note 52 and the section entitled "Marine Mammals" at pp. 474-477 below). It has been argued that the concept of "real interest" was inserted in Art. 8(3) of the 1995 Fish Stocks Agreement (Agreement for the Implementation of the Provisions of the United Nations Convention on the Law of the Sea of 10 December 1982 Relating to the Conservation and Management of Straddling Fish Stocks and Highly Migratory Fish Stocks, New York, 4 August 1995, not in force, UN Law of the Sea Bulletin, 29 (1995), p. 25; at 1 April 2001, there were 27 state parties (30 needed)) to restrict participation to those intent on harvesting (see E.J. Molenaar, "The Concept of 'Real Interest' and Other Aspects of Cooperation Through Regional Fisheries Management Mechanisms (RFMMs)", (2000) 15 International Journal of Marine and Coastal Law 475-531; and Kaye, note 7 above at p. 376).

13 As a regional economic integration organisation, the EC was, upon accession to the CCAMLR Convention, entitled to be a member of the Commission (see Arts VII(2)(c) and XXIX(2) of the CCAMLR Convention).

14 Bulgaria, Canada, Finland, Greece, Namibia, the Netherlands and Peru. While Mauritius may soon accede, Canada has expressed an intention to fish for krill, which means it must apply for membership (Doc. CCAMLR-XIX. paras 4.6 and 5.8-5.14 (advance copy)). Namibia is expected to become a member as well. 
listed in paragraph (1) of Article IX. These include facilitating research, compiling data, adopting and reviewing Conservation Measures and implementing the system of observation and inspection established under Article XXIV. ${ }^{15}$ The Commission does not set national quotas but limits certain fisheries to a fixed number of vessels and closes fisheries once the total allowable catch (TAC) has been reached. This system of "competitive" TACs, which causes a "race for fish" with a number of side-effects, has often been severely criticised and is used less and less globally. ${ }^{16}$

The Commission is assisted by the Scientific Committee, whose recommendations and advice must be taken fully into account. ${ }^{17}$ This leaves the Commission a margin of discretion that is quite common in RFMOs. ${ }^{18}$ Since the CCAMLR Convention entered into force, the Commission has established two subcommittees: the Standing Committee on Administration and Finance (SCAF), and the Standing Committee on Observation and Inspection (SCOI). ${ }^{19}$ The Scientific Committee is supported by three subsidiary working groups: (1) on ecosystem monitoring and management (WG-EMM); (2) on fish stock assessment (WG-FSA); and (3) the ad hoc Working Group on Incidental Mortality Arising from Longline Fishing (ad hoc WG-IMALF). ${ }^{20}$ Further support is provided by the Secretariat, based in Hobart. An ad-hoc Task Group is currently charged with development of a unified regulatory framework for CCAMLR fisheries. ${ }^{21}$

On matters of substance the Commission takes decisions exclusively by consensus, whereas other decisions are taken by a simple majority of the

15 Para. (2) contains a non-exhaustive list of types of Conservation Measures (CMs). The Commission occasionally adopts Resolutions as well, based, inter alia, on Arts IX(I)(h), X and XI of the CCAMLR Convention (e.g. see note 33 below). Unlike CMs, Resolutions are nonlegally binding.

16 See inter alia $\mathrm{CMs} 7 / \mathrm{V}$ and $51 / \mathrm{XIX}$. See the criticism by T. Stone, "Fishing in the Freezer: Challenges for Fisheries Managers in Australia's Sub-Antarctic Fisheries"' in S. Bateman and D.R. Rothwell (eds), Southern Ocean Fishing. Policy Challenges for Australia (Wollongong, Centre for Maritime Policy, University of Wollongong, 1998), pp. 89102 at pp. 98-100; and M. Exel, "Exploitation of Southern Ocean Fisheries: An Industry Perspective", ibid., pp. 103-113. Interestingly, pot fisheries for toothfish in Statistical Subarea 48.3 are not limited by seasons and may therefore be more competitive than longlining or trawling. This may give the United Kingdom a relatively large share of the TAC (see Docs CCAMLR-XVIII/BG/38; CCAMLRXVIII, paras 4.20-4.21 and 9.11-9.13; and CCAMLR-XIX, para. 9.23 (advance copy) and CM 196/XIX, under (4)).

17 Para. (4) of Art. IX. Art. XIV(1) observes that the Scientific Committee is a "consultative body to the Commission",

18 In the early years of the entry into force of the Convention, the role of the Committee was still controversial (see Kaye, note 7 above at p. 400).

19 Based on the Commission's competence under Art. XIII(6) of the CCAMLR Convention. The Commission still considers an adjustment of SCOI's Terms of Reference (Docs CCAMLRXVII, para. 8.19 and CCAMLR-XIX, paras 8.35-8.38 (advance copy)).

20 Established on the basis of Art. XVI(3) of the CCAMLR Convention. WG-EMM has also established two subgroups: the Subgroup on Statistics and the Subgroup on Monitoring Methods, as well as several ad hoc subgroups.

21 Doc. CCAMLR-XIX, paras 10.2-10.8 (advance copy). 
members present and voting. 22 "Consensus" is not defined but is applied as meaning the absence of formal objection. To accommodate those members that do not want to oppose consensus but nevertheless want to avoid becoming legally bound by Conservation Measures, Article IX(6)(c) and (d) of the CCAMLR Convention contains an opt-out procedure. ${ }^{23}$ Instead of opting out, members may also prefer to voice their (informal) objections in Commission reports. ${ }^{24}$ Consensus was blocked relatively often in the early years of the Commission, but has functioned quite satisfactorily ever since. ${ }^{25}$ The power to block consensus obviously remains a very important negotiating tool. Contracting parties must take appropriate measures to ensure compliance with Conservation Measures to which they are bound and report relevant information thereon to the Commission. ${ }^{26}$ It goes without saying that not all contracting partics always fully comply with all aspects of each Conservation Measure.

\section{Aspects of Spatial and Substantive Competence}

The regulatory area of the CCAMLR Convention is defined in Article I(1), which provides: "This Convention applies to the Antarctic marine living resources of the area south of $60^{\circ}$ South latitude and to the Antarctic marine living resources of the area between that latitude and the Antarctic Convergence which form part of the Antarctic marine ecosystem."27 Paragraph (4) lists the geographical coordinates that are "deemed to be" the Antarctic Convergence. The CCAMLR Convention Area thus comprises FAO Statistical Areas 48, 58 and 88. The spatial coverage of the CCAMLR Convention is the only instrument in the Antarctic Treaty System (ATS) that departs from the (less extensive)

22 Art. XII(1) and (2) of the CCAMLR Convention. Para. (1) also provides that "The question of whether a matter is one of substance shall be treated as a matter of substance." Paras (3) and (4) deal with the voting procedure for regional economic integration organisations such as the EC. See also Art. XIX on the budget, in particular para. (6).

23 C. Redgwell, "The Protection of the Antarctic Environment and the Ecosystem Approach" in C. Redgwell and M. Bowman (eds). International Law and the Conservation of Biological Diversity (The Hague, Kluwer Law International, 1995), pp. 109-128 at p. 120, refers to this as the "double veto". While many RFMOs use either consensus or opting-out procedures, very few use both. Redgwell submits that this double veto is the result of the special sovereignty situation in Antarctica.

24 In relation to the EC notification on behalf of Portugal (discussed in the section entitled "The Characterization of the CCAMLR Convention and the Role of the EC" at pp. 490-497 below), both alternatives were used. Certain members can also invoke the Chairman's Statement to ensure that Conservation Measures do not apply to certain maritime areas within their jurisdiction (sce the section entitled "Antarctic Territorial Claims and Sub-Antarctic Islands" at 5 pp. 477-482 below).

25 Cf. S. Kayc, "CCAMLR and Southern Ocean Fishcries" in Bateman and Rothwell, note 16 above at pp. 7583 at p. 77 . See also Kaye, note 7 above at pp. 399-407.

26 Art. XXI of the CCAMLR Convention. See also Arts XXII and XXIV.

27 Para. (2) defines "Antaretic marine living resources" as "the populations of fin fish, molluses, crustaceans and all other species of living organisms, including birds, found south of the Antarctic Convergence". 
spatial coverage of the Antarctic Treaty. ${ }^{28}$ As the Antarctic Convergence represents in reality a hydrological boundary between warmer and cooler waters, this lessens the need to harmonise management and conservation efforts with adjacent RFMOs and states. ${ }^{29}$ A number of provisions have nevertheless been incorporated in the CCAMLR Convention to address this need.

Article IX on the function of the Commission stipulates in paragraph (5) that the Commission shall take full account of regulatory efforts established or recommended:

"by existing fisheries commissions responsible for species which may enter the area to which this Convention applies, in order that there shall be no inconsistency between the rights and obligations of a contracting party under such regulations or measures and conservation measures which may be adopted by the Commission." 30

Whereas this commitment only addresses the need to respect the efforts of other RFMOs, there is a corresponding need for other RFMOs to respect the efforts of the Commission. Patagonian toothfish, squid (Martialia hyadesi) and lanternfish (Electrona carlsbergi) are for instance caught not only within the CCAMLR Convention Area but also in adjacent arcas in the Atlantic, Indian and Pacific Oceans. ${ }^{31}$ Article XI of the CCAMLR Convention therefore requires the Commission to co-operate with contracting parties with respect to stocks that also occur in the maritime zones of these states adjacent to the CCAMLR Convention Area. These areas may not fall within the competence of an RFMO ${ }^{32}$ Currently there is insufficient scientific evidence to determine whether

The Antarctic Treaty (Washington DC, 1 December 1959, in force 23 June 1961, (1961) 402 UNTS 71; www.antdiv.gov.au), Art. VI.

29 The CCAMLR Convention Area is regarded by some as the only large marine ecosystem (LME) that is currently managed by an ecosystem approach (sce L.M. Alexander, "Large Marine Ecosystems as Global Management Units" in K. Sherman and L.M. Alexander (eds), Biomass Yields and Geography of Large Marine Ecosystems (Boulder, CO, Westview Press, 1989), pp. 339-344 at p. 342). However, certain species nevertheless straddle its boundaries (see the main text below).

30 See also Art. XXIII of the CCAMLR Convention, which refers to the need for co-operation with a number of international organisations.

$31 \mathrm{Cf}$. "Understanding CCAMLR's Approach to Management", note 2 above at pp. 8 and 12. Krill seems to consist of one homogenous population. The Pacific Ocean is listed to account for catches in the maritime zones of the sub-Antarctic islands of Australia and New Zealand (see note 32 below). Several bird species that breed within the CCAMLR Convention Area also die because of longlining in adjacent areas. The presence of toothfish in high seas areas beyond both the CCAMLR Convention Area and the EEZ around Kerguelen island was inter alia disputed in the Monte Confurco case (Seychelles v France, Application for Prompt Release, Judgment of the International Tribunal for the Law of the Sea (ITLOS) of 18 December 2000) (see ITLOS/ PV.00/05, p. 11 and paras 54-55 and 88 of the Judgment; text of both at www.un.org/Depts/los).

32 Patagonian toothfish also occur in the maritime zones off southern Argentina and Chile, the Falkland Islands (claimed by Argentina and the United Kingdom) and Macquarie Island (Australia) (cf. R. Herr, "The International Regulation of Patagonian Toothfish: CCAMLR and High Seas Fisheries Management" in O.S. Stokke (ed.), Governing High Seas Fisheries: The 
Patagonian toothfish should be regarded as one single (straddling) stock, or if it is composed of several distinct stocks. ${ }^{33}$

The definition in Article I(1) implies that the CCAMLR Convention Area only overlaps with the coverage of both the CCSBT Convention and (potentially) the ICCAT Convention, both of which are concerned with tuna or tuna-like species. ${ }^{34}$ The southern boundaries of a number of regulatory areas of other RFMOs coincide with the northern boundary of the CCAMLR Convention Area: the IOTC Agreement, ${ }^{35}$ the Honolulu Convention, ${ }^{36}$ the Galapagos Agreement, ${ }^{37}$ the SEAFO Convention ${ }^{38}$ and the prospective SWIOFC Agreement. ${ }^{39}$ Except for the CCSBT Convention, the ICCAT Convention and the IOTC Agreement, which deal exclusively with tuna or tuna-like species, ${ }^{40}$ a need to co-operate with the Commission would be relevant for the other four RFMOs. ${ }^{41}$

contd.

Interplay of Global and Regional Regimes, forthcoming in 2001, around note 12). The ISOFISH website, www.isofish.org.au, also lists the maritime zones around New Zealand's subAntarctic islands.

$33 \mathrm{Cr}$. Herr, note 32 above, around notes $58 \cdot 61$, who refers to ongoing discussions in the Scientific Committee between 1990 and 1995. Note that CCAMLR Resolution 10/XIl ("Resolution on Harvesting of Stocks Occurring Both Within and Outside the Convention Area") inter alia "reaffirmed that Members should ensure that their flag vessels conduct harvesting of such stocks in areas adjacent to the Convention Area responsibly and with due respect for the Conservation Measures it has adopted under the Convention". Note that the Catch Documentation Scheme applies also beyond the CCAMLR Convention Area (see note 115 below). See also the discussion on the categorisation of stocks in E.J. Molenaar, "The South Tasman Rise Arrangement of 2000 and Other Initiatives on Management and Conservation of Orange Roughy", (2001) 16 International Journal of Marine and Coastal Law 77-124.

34 The Convention for the Conservation of Southern Bluefin Tuna (Canberra, 10 May 1993, in force 20 May 1994, www.home.aone.net.au/ccsbt) does not really have a regulatory area but is concerned with a single tuna species, wherever it occurs (Art. 1). The regulatory area of the International Convention for the Conservation of Atlantic Tunas (Rio de Janeiro, 14 May 1966, in force 21 March 1969, www.iccat.es) are "all waters of the Atlantic Ocean, including the adjacent Seas" (Art. I).

35 Art. II of the Agreement for the Establishment of the Indian Ocean Tuna Commission (Rome, 25 November 1993 (105th Session of the FAO Council), in force 27 March 1996, www.fao.org/ legal)

36 Art. 3(1) of the Convention on the Conservation and Management of Highly Migratory Fish Stocks in the Western and Central Pacific Occan (Honolulu, 5 September 2000, not in force). See the Appendix to the article by Transform Aqorau in this issue.

37 Art. 3 of the Framework Agrecment for the Conservation of the Living Marine Resources on the High Seas of the Southeast Pacific (Santiago, 14 August 2000, not in force).

38 Art. 4 of the Convention on the Conservation and Management of the Fishery Resources in the South East Atlantic Ocean, Windhoek, 20 April 2001, not in force, text on file with author.

39 Art. III of the Draft Agreement for the Establishment of a South West Indian Ocean Fisheries Commission (First Intergovernmental Consultation (Third Meeting), February 2001).

40) Art 1 of the CCSBT Convention; Art. IV of the ICCAT Convention; and Art. III and Annex B to the IOTC Agreement.

41 See Arts I(I), 2 and 22(2) of the Honolulu Convention (Art. 22(2) refers to the Commission (CCAMLR)); Arts 1.12, 1.13, 2 and 4 of the Galapagos Agreement; Arts 1(1), 2 and 18(4) of the SEAFO Convention; and Arts IV(1) and IX(1) of the Draft SWIOFC Agreement (Second Meeting, July 2000). 
Another interesting case of shared or complementary competence is that between the Commission and the Convention on International Trade in Endangered Species of Wild Fauna and Flora (CITES), ${ }^{42}$ under which international trade in species that are momentarily threatened with extinction or are likely to be so in the near future, can be subjected to various restrictions, including trade-bans. ${ }^{43}$ Species listed in one of the three Appendices to CITES would oblige contracting partics to CITES to regulate their trade only in accordance with CITES. While steps to protect toothfish under CITES have been propagated, within the Commission such a course of action is not yet seriously contemplated. ${ }^{44}$ As toothfish is a commercially exploited fish species, it is at any rate necessary to await the outcome of the work of the Subcommittee on Fish Trade, established under the FAO's Committee on Fisheries (COFI) and the FAO "Technical Consultation on the Suitability of the CITES Criteria for Listing Commercially Exploited Aquatic Species", held in Rome in June 2000. The 24th Session of COFI, to be held in February 2001, will make a decision "on whether to express opinions and recommendations to CITES on the existing CITES listing criteria as they apply to commercially exploited aquatic species and, if so, the nature of these". 45 Of particular importance for such CITES listings would be the respective roles of RFMOs and contracting parties thereto.

Finally, the CCAMLR Convention acknowledges "the special obligations and responsibilities of the Antarctic Treaty Consultative Parties for the protection and preservation of the environment of the Antarctic Treaty area" ${ }^{46}$ This calls for co-operation between bodies under the CCAMLR Convention and other bodies in the ATS, in particular the Committee for Environmental Protection (CEP), established under Article 11(1) of the Madrid Protocol. ${ }^{47}$ The New Zealand proposal at the 19th Commission Meeting (2000) to establish a Balleny Islands Specially Protected Area (SPA) is an interesting case as Annex V to the

42 Washington DC, 3 March 1973, in force 1 July 1975, text available at www.wemc.org.uk/ CITES.

4.3 Art. I(c) of CITES defines "trade" as "cxport, re-cxport, import and introduction from the sea", whereas Art. I(e) defines "introduction from the sea" as "transportation into a State of specimens of any species which were taken in the marine environment not under the jurisdiction of any State".

44 See, for instance, the remarks by the representative from ASOC in Doc. CCAMLR-XVIII, para. 12.3. See also Doc. CCAMLR-XVIII/BG/50 Rev. 1 (Chile), p. 7. At the $18 \mathrm{th}$ Commission Meeting (1999), "Korea considered, however, that increased interaction with CITES would not be appropriate" (Doc. CCAMLR-XVIII, para. 13.10).

45 FAO Doc. FI:SLC/2000/2 (available at www.fao.org/fi/publ/publ.asp), para. 8.

46 Art. V(1). See also the other paragraphs and Arts IX(5) and XXIII(1).

47 Protocol on Environmental Protection to the Antarctic Treaty, Madrid, 4 October 1991 (Annexes I IV), in force 14 January 1998. Annex V, Bonn, 17 October 1991, nol in force, adopted as Recommendation XVI-10, Final Report of the Sixteenth ATCM, pp. 116-125. Whereas Annex II, entitled "Conservation of Antarctic Fauna and Flora", is the most relevant to the Commission, Arts 1(b) and 5(1) of Annex IV deal with the prevention of marine pollution by fishing nets. 
Madrid Protocol has not yet entered into force. ${ }^{48}$ Other relevant efforts of the CCAMLR Commission include the various Conservation Measures to minimise incidental mortality of seabirds and marine mammals ${ }^{49}$ and those relating to CEMP (CCAMLR Ecosystem Monitoring Program) sites. ${ }^{50}$ Further cooperation or alignment may be warranted in view of calls to develop an Agreement on the Conservation of Southern Hemisphere Albatrosses and Petrels under the Bonn Convention (Convention on the Conservation of Migratory Species of Wild Animals). ${ }^{51}$

\section{Marine Mammals}

A well-known provision in the CCAMLR Convention is Article VI, which provides that "[n]othing in this Convention shall derogate from the rights and obligations of contracting parties under the International Convention for the Regulation of Whaling [IWC Convention] ${ }^{52}$ and the Convention for the Conservation of Antarctic Seals [CCAS Convention]" ${ }^{13}$. The Commission will therefore in principle not regulate whaling and sealing in the CCAMLR Convention Area, even though the definition of "Antarctic marine living resources" in Article I(2) would allow this. ${ }^{54}$ Large-scale commercial sealing in Antarctica has not taken place since the CCAS Convention's entry into force and currently there is no interest in a resumption. ${ }^{55}$

The situation with regard to whaling is more complex due to disagreement on the objectives and legitimacy of the IWC Commission, which inter alia agreed on a general moratorium on commercial whaling in 1986 and established a Southern Ocean Sanctuary in 1994. ${ }^{56}$ Japan nevertheless continues to catch minke whales

See Doc. CCAMLR-XIX, paras 11.1-11.28 (advance copy). Annex V is entitled "Area Protection and Management" (see also Art. 6(2)). New Zealand will submit a redrafted proposal at the next Commission Meeting.

49 See CMs 29/XVI, 63/XV, 173/XVIII, 182/XVIII and 29/XIX.

50 See CMs 62/XI, 82/XII, 18/XIII and 18/XIX. Paras 5-8 of CM 18/XIX specifically concern cooperation with the Contracting and Consultative Parties to the Antarctic Treaty.

st Cf. Doc. CCAMLR-XIX, paras 6.27 and 12.28-12.29 (advance copy). See also www.wemc. org.uk/cms.

52 Washington DC, 2 December 1946; in force 10 November 1948. As amended by the 1956 Protocol, Washington DC, 19 November 1956; date of entry into force varies among states. Both texts at ourworld.compuserve.com/homepages/iwcoffice. The IWC Convention is not part of the ATS.

53 London, 11 February 1972, in force 13 March 1978, text at www.antdiv.gov.au. The CCAS Convention is part of the ATS and concerned with the conservation, scientific study and rational and humane use of seal resources by, inter alia, providing total protection to certain species and establishing catch limits for others.

54 Scc note 27 above. See also Art. XXIII(3).

55 See D.R. Rothwell, "The Antarctic Treaty System and the Southern Ocean" in Bateman and Rothwell, note 16 above, pp. 5-40 at pp. 1416.

56 See paras 7(b) and 10(e) of the Schedule to the IWC Convention (as amended by the IWC Commission at the 51st Annual Meeting 1999, text at ourworld.compuserve.com/homepages/ iwcoffice). The Southern Occan Sanctuary encompasses all the waters in the CCAMLR Convention Area and certain adjacent areas. 
in the Southern Ocean, which it regards as justified by its reservation to the Southern Ocean Sanctuary to the extent that it applies to the Antarctic minke whale stocks and also by its more general reliance on the "scientific exception". 57 Japan criticises the IWC Commission for basing its decisions on political and emotional factors rather than on science. Several other states that also favour a resumption of commercial whaling and a number of scholars share this view. ${ }^{58}$ Pressure is therefore mounting on the IWC Commission to finalise and adopt the Revised Management Scheme (RMS), which would allow such resumption. ${ }^{59}$ Japan hopes this will be accomplished at the 54th Annual Meeting of the IWC Commission, which is scheduled to take place in 2002, in Shiminoseki, Japan.

Various scenarios exist when Japan's hopes do not materialise. Relevant to this article are the potential implications for the CCAMLR Commission. It was already observed that Article VI in conjunction with Article I(2) of the CCAMLR Convention would not prohibit the regulation of whaling, provided certain conditions are met. But consensus decision-making and the fact that the main antagonists in the IWC Commission are also members of the CCAMLR Commission, render this rather unlikely. ${ }^{60}$ At the same time, it implies that the CCAMLR Commission will not be able to combat whaling in a similar way to IUU fishing. Morcover, while states may engage in whaling in the CCAMLR Convention Area on an individual basis, as Japan currently does, they may also opt for regional co-operation. A precedent already exists in the establishment of the North Atlantic Marine Mammal Commission

57 See the objections under paras 6 and $7(b)$ to the Schedule (pursuant to Art. V(3) of the IWC Convention) and Art. VIII(1) of the IWC Convention.

58 See inter alia D.D. Caron, "The International Whaling Commission and the North Atlantic Marine Mammal Commission: The Institutional Risks of Coercion in Consensual Structures", (1995) 89 American Journal of International Law 154-174; W.T. Burke, "Legal Aspects of the IWC Decision on the Southern Ocean Sanctuary", (1997) 28 Ocean Development and International Law" 313-327; A. Gillespie, "The Southern Ocean Sanctuary and the Evolution of International Environmental Law", (2000) 15 International Journal of Marine and Coastal Law 293-316.

59 IWC Resolution 2000-3 reflects awareness of this pressure by inter alia considering that "it is important for the future of the Commission that the process of completion of the RMS proceed expeditiously" (text at ourworld.compuserve.com/homepages/iwcoffice).

60 Special note should here be taken of Japan's forum-shopping efforts in relation to southern bluefin tuna. Japanese attempts to establish a Working Party on Temperate Tunas within the framework of the IOTC Agreement are motivated by Japan's dissatisfaction with the situation under the CCSBT Convention. The fact that the IOTC Commission takes decisions by a twothirds majority (Art. IX(1)) whereas the CCSBT takes decisions by unanimity (Art. 7), seems to play a prominent role. At the Third IOTC Session (1998), the IOTC Commission adopted Resolution 98/03, "On Southern Bluefin Tuna", which, inter alia, reaffirmed "the prime responsibility of CCSBT" over southern bluefin tuna. A Working Party on Temperate Tunas was apparently established at the Fifth IOTC Scssion (2000) but with very restrictive terms of reference relating to southern bluefin tuna (see the Australian opposition at the Fourth IOTC Session (1999) (Report, paras 23-24)). Text of IOTC Resolution and Report available at www.seychelles.net/iote. 
(NAMMCO) in 1992.61 A crucial distinction with NAMMCO is that such a prospective regional mechanism would compete geographically and substantively with not just the CCAMLR Convention and the CCAS Convention, but in fact the entire ATS. The chance that states participating in the firmly established and highly developed co-operative framework of the ATS will allow such a competitor to establish itself, is extremely small. ${ }^{62}$

It is submitted, however, that the relevance of such scenarios may be overtaken by other developments. Whales affect the CCAMLR Commission because they feed on some of its target species: krill and squid. Moreover, seals, penguins and other birds feed on these and other target finfish species. Understanding functional relationships between target and non-target species is one of the challenges of management and conservation under the CCAMLR Convention. In fact, while the krill fishery is currently (still) relatively small, concern for its potential impact on whales was the main catalyst for adherence to the ecosystem approach. ${ }^{63}$ Sooner or later, non-human predators may become so abundant that their take of target species seriously competes with human exploitation. Balancing the relative interests of competitors is a challenge that is not unique for the Southern Ocean, but is one that will have to be met globally, in most, if not all, fisheries. ${ }^{64}$ In the not so distant future, the exploitation of marine mammals may therefore also be motivated in order to limit their "allocation" of other species. ${ }^{65}$ At which level such exploitation will take place, globally, regionally, or both, is difficult to predict. The fundamental moral dilemmas of such an allocation are considerable, but economic and protein needs are expected to weigh heavier than ending human exploitation altogether. The Southern Ocean may nevertheless be treated as a special case due to the significant role of non-human predators whose exploitation may not be

61 Agreement on Cooperation in Research, Conservation and Management of Marine Mammals in the North Atlantic, Nuuk, 9 April 1992, in force 8 July 1992, UN Law' of the Sea Bulletin, 26 (1994), pp. 66 68. As at 1 December 2000, the parties were the Faroe Islands, Greenland, Iceland and Norway. For more information, see Caron, note 58 above; and the NAMMCO website at www.nammco.no. Note also the Canada/Greenland Joint Commission on the Conservation and Management of Narwhal and Beluga (JCNB). Caron, note 58 above at pp. 156 and 173, refers to the possibility of a Japanese regional initiative in the Pacific.

62 O.S. Stokke, "The Effectiveness of CCAMLR" in O.S. Stokke and D. Vidas (eds), Governing the Antarctic: The Effectiveness and Legitimacy of the Antarctic Treaty System (Cambridge, Cambridge University Press, 1996), p. 120 at p. 131, notes that the CCAMLR Convention was in part established to pre-empt an FAO initiative.

63 Cf. J.A. Gulland, "The Management Regime for Living Resources" in C.C. Joyner and S.K. Chopra (cds), The Antarctic Legal Regime (Dordrecht, Boston and London, Martinus Nijhoff Publishers, 1988), pp. 219-240 at p. 229.

64 See inter alia Gulland, ibid., pp. 230-231 and the attention to the "Economic Aspects of Marine Mammal Fisheries Interactions" at the 10th NAMMCO Meeting (2000), which also applauded Japanese research in the Western North Pacific (Final Press Release of 28 September 2000 at www.nammco.no).

65 Alternatively, larger populations of marine mammals and unrelenting human exploitation will lead to the collapse of these "other species". 
acceptable, namely penguins and other birds. ${ }^{66}$ In such a scenario, the prohibition of all exploitation of living resources in the Southern Ocean may be the most opportune solution.

\section{Antarctic Territorial Claims and Sub-Antarctic Islands}

The contested claims to Antarctica lie at the very heart of the Antarctic Treaty and the ATS. As these issues are discussed in more detail elsewhere, ${ }^{67}$ mention is only made of three main points. First of all, pursuant to Articles IV and VI of the Antarctic Treaty, state parties have opted for an agreement to disagree on Antarctic territorial claims. Article IV of the CCAMLR Convention makes these provisions applicable to state parties to the CCAMLR Convention, and reiterates their substance. ${ }^{68}$ This has deflected emphasis from irreconcilable positions towards co-operation in addressing particular issues. Ever since the adoption of the Antarctic Treaty, the ATS has therefore expanded with an increasing emphasis on the protection of Antarctica and the Southern Ocean. ${ }^{69}$

Secondly, as a consequence of the disputed status of Antarctica, claims to sovereignty, sovereign rights and jurisdiction over waters adjacent to Antarctica, as well as their exercise, are controversial. ${ }^{70}$ Claimant states have therefore not controlled marine living resources in waters adjacent to Antarctica like coastal states would do elsewhere. For example, while Australia proclaimed an EEZ off its territory in 1994, including the Australian Antarctic Territory (AAT), it continues to use an Australian Fishery Zone (AFZ) for fisheries regulation. The waters off the AAT are "excepted waters" within the AFZ, and the AFZ provisions are therefore only applicable to Australian fishing activities.71 Effectively, this is an exercise of jurisdiction under the nationality principle (also called active personality principle) and therefore similar to jurisdiction over Australian fishing activities on the high seas. ${ }^{72}$ Other claimant states, such as

66 Jurisdiction over Vessel-Source Pollution (The Hague, Boston and London. Kluwer Law International, 1998), pp. 443-451. Commonwealth of Australia Gazette, 2 November 1979, No. S225; and W. Fletcher, "Australian Law in Antarctica and the Southern Ocean" in Bateman and Rothwell, note 16 above at pp. 69.70. See also the comments on South Georgia and the South Sandwich Islands in notc 75 below.

72 New Zealand currently exercises jurisdiction under the nationality principle by way of the Antarctic Marine Living Resources Act 1981 (No. 53, as amended) and "departure" port state jurisdiction based on the Antarctica (Environmental Protection) Act 1994 (No. 119; see ss. 2(d)(ii). 7(1) and 1719). However, s. 9(3) of the Territorial Sea and Exclusive Economic Zone Act 1977 of New Zealand (No. 28 of 26 September 1977, as amended) allows New Zealand to declare an EEZ off its claim to Antarctica. Text of acts at www.knowledge-basket.co.nz/gpprint. See also note 133 below. 
Argentina and Chile, take a more assertive attitude by explicitly or implicitly prescribing activities within their claimed maritime zones off Antarctica. However, they have never pursued a rigorous policy of enforcement vis-à-vis foreign vessels and nationals, no doubt in view of Article IV of the Antarctic Treaty. ${ }^{73}$ All these policies imply that the special status of waters adjacent to Antarctica raises issues of the effectiveness of conservation and management in a similar way as regards the high seas.

Nothing prevents any state from exercising prescriptive jurisdiction over its vessels and nationals with regard to fishing activity anywhere in the CCAMLR Convention Area. Enforcement action against a state's own vessels or nationals is a less straightforward case. While it is obviously permitted on the high seas and also within an EEZ off undisputed territory, ${ }^{74}$ in the territorial sea off undisputed territory a flag state is either required, but in any case advised, to consult that coastal state on the appropriateness of action taken. Within the claimed maritime zones off Antarctica, such enforcement action may be treated as less problematic because Article IV of the Antarctic Treaty assures both the flag state and the claimant state that this action has no implications on sovereignty.

Thirdly, as the Antarctic Treaty area extends south of $60^{\circ}$ South latitude (Art. VI), a number of sub-Antarctic islands fall beyond the Treaty's scope. Some of these islands, and (part of) their maritime zones, are nevertheless included in the CCAMLR Convention Area, namely Heard and McDonald Islands (Australia), Kerguelen and Crozet Islands (France), Bouvetøya Island (Norway), Prince Edward and Marion Islands (South Africa), and South Georgia and the South Sandwich Islands ${ }^{75}$ and Shag Rocks (claimed by Argentina and the United Kingdom, but under the "effective control" of the latter). It is worth noting that the dispute over South Georgia, with the Falkland Islands looming in the background, frequently interferes with co-operation within the framework of the CCAMLR Convention. This consumes time and energy that could otherwise be used much more productively. ${ }^{76}$

73 Sec F. Orrego Vicuña, "The Law of the Sea and the Antaretic Treaty System: New Approaches to Offshore Jurisdiction" in Joyner and Chopra, note 63 above at pp. 97-127 at p. 108.

74 C.f. Art. 92(1) in conjunction with Art. 58(2) of the LOS Convention (United Nations Convention on the Law of the Sea, Montego Bay, 10 December 1982, in force 16 November 1994, (1982) 21 ILM 1245).

75 The South Georgia and the South Sandwich Islands group is not a dependency of the Falkland Islands but is since 1985 a separate territory with its own Constitution. The 200-nm maritime zone around South Georgia and the South Sandwich Islands extends south of 60 . South into the Antarctic Treaty area. However, in order to avoid any complications with the Antarctic Treaty, the fishing legislation for the zone docs not apply south of $60^{\circ}$ South (based on Doc. CCAMLRXVIII, para. I3.4).

$76 \mathrm{CF}$. the views expressed by France and the United Kingdom in Doc. CCAMLR-XVIII, paras 13.3-13.4 in relation to the heated debate following the submission of a Chilcan document at the 18th Commission Meeting (1999) (Doc. CCAMLR-XVIII/BG/50 Rev. 1). A similar situation had arisen at the 15th Commission Meeting (1996) (see Doc. CCAMLR-XV, pp. 81-88). A strict approach is of course not taken at all levels. Apparently, several Argentinean vessel owners now 
Many of the commercially interesting species, including Patagonian toothfish, are predominantly found in the maritime zones of these sub-Antarctic islands. ${ }^{77}$ The spatial coverage of the CCAMLR Convention was therefore only acceptable with assurances that the status of these sub-Antarctic islands and the sovereignty, sovereign rights and jurisdiction over their maritime zones would not be affected. Eventually, this led to the incorporation of subparagraphs (b) and (c) of Article IV(2), which provide that:

"Nothing in this Convention and no acts or activities taking place while the present Convention is in force shall:

(a) $\ldots$

(b) be interpreted as a renunciation or diminution by any contracting party of, or as prejudicing, any right or claim or basis of claim to exercise coastal state jurisdiction under international law within the area to which this Convention applies;

(c) be interpreted as prejudicing the position of any contracting party as regards its recognition or non-recognition of any such right, claim or basis or claim."

These provisions achieve two distinct objectives. Apart from the issue of subAntarctic islands above $60^{\circ}$ South, they also address the more general controversy over maritime zones. In respect of the latter, the wording of the provisions creates what has been termed "constructive ambiguity" or a "bifocal approach". ${ }^{78}$ Essentially it caters for both claimants and non-claimants to sections of Antarctica as the provisions can be interpreted as either confirming the right to exercise coastal state jurisdiction throughout the CCAMLR Convention Area or as limiting this right to islands north of $60^{\circ}$ South. As such this bifocal approach complements the agreement to disagree specifically in relation to maritime zones.

The CCAMLR Convention does not otherwise touch upon the scope of coastal state jurisdiction over marine living resources but this was nevertheless given special attention during the various meetings of the Conference that negotiated the CCAMLR Convention. The Conference ultimately decided to include in the Final Act of the Conference a statement by the Conference Chairman "regarding the application of the [CCAMLR Convention] to the waters adjacent to Kerguelen and Crozet over which France has jurisdiction and to waters adjacent to other islands within the area to which this Convention

contd.

register their vessels in Chile and subsequently apply for fishing licences in the maritime zones of the disputed islands. At the 19th Commission Meeting (2000) Argentina once again made several sovereignty statements (Doc. CCAMLR-XIX, paras 5.17 5.19, 5.22 and 9.9 (advancc copy)).

77 See also note 32 above.

78

Cf. Orrego Vicuña, note 73 above at p. 111. 
applies over which the existence of state sovereignty is recognised by all Contracting Parties" (hereinafter, the "Chairman's Statement"). ${ }^{79}$ The Chairman's Statement effectively recognises France's considerable margin of discretion in prescribing and enforcing conservation measures with respect to the maritime zones off Kerguelen and Crozet Islands. ${ }^{80}$ Moreover, paragraph (5) of the Statement ends by observing that:

"These understandings ... also apply to waters adjacent to the islands within the area to which this Convention applies over which the existence of State sovereignty is recognised by all contracting parties.

No objection to the statement was made."

Even though this statement is neither formally attached to the Convention nor linked to a contracting party's reservation, it has in general been respected throughout the life of the Commission. ${ }^{81}$ France has ensured that a large number of Conservation Measures are not applicable to the waters adjacent to Kerguelen and/or Crozet. Of the other states with relevant sub-Antarctic islands only South Africa makes frequent reservations for the waters off Prince Edward Islands. However, when it does so, it nevertheless incorporates the Measures into its national legislation. ${ }^{82}$ Australia, Norway and the United Kingdom (and Argentina) thus take a different approach by not invoking the Chairman's Statement. ${ }^{8.3}$ It is nevertheless important to realise that, even though Conservation Measures may apply within their maritime zones, Article IV(2)(b) and (c) of the Convention leaves these states' competence to regulate access,

Statement of 19 May 1980, available at www.ccamlr.org.

80) The Chairman's Statement inter alia observes that French conservation measures adopted prior to the entry into force of the CCAMLR Convention would remain in force (Chile, in Doc. CCAMLRXVIII/BG/50 Rev. 1, p. 2 argues this is a French prerogative only), that France would have the right to cxclude these maritime zones from the scope of application of CMs, and the right to adopt its own (stricter) measures; and retain full enforcement competence without having to implement the system of observation and inspection under Art. XXIV of the CCAMLR Convention. Cf. Rothwell, note 55 above at p. 18. Argentina regards the Statement as having treaty status (Doc. CCAMLR-XIX, para. 13.3 (advance copy)). Sec also A. Aust. Modern Treaty Law and Practice (Cambridge. Cambridge University Press, 2000), pp. 189190.

82 Reservations to CMs are visible through footnotes that refer to excepted waters. References to the Prince Edward Islands include both Prince Edward and Marion Island. The CMs are incorporated in the Marine Living Resources Act (No. 18 of 1998, text at www.gov.za/acts) or the Antarctic Treaty Act (No. 60 of 1996, text at www.polity.org.za/govdocs/legislation) (information kindly provided by D. Miller).

83 In view of the sovereignty dispute over South Georgia and the South Sandwich Islands and Shag Rocks, the question arises whether the United Kingdom (or Argentina) is entitled to invoke the Chairman's Statement. Kaye, note 7 above at p. 388. who rejects such a possibility, places apparently a decisive emphasis on the aspect of "recognition". D. Vignes, "Protection of the Antarctic Marine Fauna and Flora: The Canberra Convention of 20 May 1980 and the Commission Set Up By It" in F. Francioni and T. Scovarri (eds), International Law for Antarcfica (The Hague. London and Boston. Kluwer Law International, 2nd ed., 1996), p. 159 at pp. 162-163, seems to take a similar view. Conversely, UK Government officials would probably emphasise that the "existence of State sovereignty" as such, if not the attribution, is the crucial issue (see Watts, note 7 above at pp. 152-153). As that is not disputed, in contrast with Antarctica, the United Kingdom (or Argentina) would be entitled to invoke the Statement. 
and thereby revenues, unaffected. Obviously, access regulation must be in compliance with Conservation Measures, which implies for instance that, once the TAC has been reached, these states should close the fishery as well.

The extent to which states can invoke the Chairman's Statement is nevertheless the subject of continuous scrutiny by states that feel that these "prerogatives" should give way to increased efforts to attain harmonisation. ${ }^{84}$ While these objections may prima facie be legitimate, it is not evident that these states pursue the same view elsewhere. RFMOs that have high seas within their regulatory area normally recognise a measure of discretion by coastal states on account of their sovereignty and sovereign rights over maritime zones within or adjacent to that regulatory area. ${ }^{85}$ There seem to be no immediate reasons why the CCAMLR Convention should be different. Arguably, the practice by Australia and in principle also Norway, the United Kingdom and South Africa constitutes a rather co-operative example of applying the complex concept of compatibility as laid down in Article 7(2) of the 1995 Fish Stocks Agreement. ${ }^{86}$

The point of departure for an overall assessment of the legal regime of the waters covered by the CCAMLR Convention Area is that it consists of a mix of high seas and both contested and uncontested coastal state maritime zones. The extraordinary feature of the contested maritime zones south of $60^{\circ}$ South is that it effectively involves the entire community of states. ${ }^{87}$ It is therefore unlike the dispute over South Georgia between Argentina and the United Kingdom, where

contd.

The fact that both states have so far abstained from doing so is not just a matter of a cooperative attilude but also warranted for reasons of diplomacy. See the comments by the United Kingdom in Doc. CCAMLR-XVIII, para. 13.4 (also discussed in note 75 above). In the AFZ off the Australian sub-Antarctic islands, the Fisheries Management Act 1991 (Cth, No. 162) takes precedence over the Antarctic Marine Living Resources Conservation Act 1981 (Cth, No. 30) (both texts at www.austlii.edu.au/au/legis/cth/consol_act). While these acts would allow for additional management and conservation measures (e.g. s. 24 of the 1981 Act and s. 168 of the 1991 Act), there is no obligation under the 1991 Act to implement CCAMLR CMs (cf. Stone, note 16 above at p. 101). Norway does not claim or exercise sovercign rights or jurisdiction in the areas adjacent to Bouvetøya Island (cf. Herr, note 32 above, around note 49).

84 See, for instance, the discussion during the 14th Commission Mecting (1995) where Argentina, Brazil and Chile argued the need for uniformity, whereas Australia. France, Norway and South Africa emphasised the enhanced effectiveness inherent in national regulation (Doc. CCAMLRXIV, pp. 68 74). In Doc. CCAMLR-XIX, para. 13.3 (advance copy) Argentina reiterates its view.

85 For that reason, the regulatory areas of many RFMOs only apply to the high seas (e.g. the SEAFO Convention (Preamble and Art. 4: note 38 above) and the Galapagos Agreement (Art. $3(1)$; note 37 above)). Where the regulatory area also includes coastal states' maritime zones, provision is made to reflect their discretion (e.g. the Honolulu Convention (Arts 7-8; note 36 above) and the IOTC Agreement (Art. XVI; note 35 above)).

86 See note 12 above. See also, in this specific context, Doc. CCAMLR-XVIII/BG/50 Rev. 1 (Chile), pp. 2-3; and A.G. Oude Ellerink. "The Impact of Articlc 7(2) of the Fish Stocks Agreement on the Formulation of Conservation and Management Measures for Straddling and Highly Migratory Fish Stocks" (FAO Legal Papers Online \#4, 1999), available at www.fao.org/ legal. See also Resolution 10/XII. note 33 above.

87 This is implicit in the fact that in principle any state can accede to the Antarctic Treaty (Art. XIII(1)) or the CCAMLR Convention (see note 10 above). 
the disagreement only concerns a few states. Consequently, if one chooses to characterise the legal framework in Antarctica in terms of joint jurisdiction ${ }^{88}$ it should be clear that this is primarily based on co-operation whereas the rights and freedoms of third states remain largely unaffected, at least with respect to the law of the sea. ${ }^{89}$ Various scholars have nevertheless advocated erga omnes approaches, for instance by relying on objective regime theories. ${ }^{90}$ Currently, however, there are no signs that the Commission intends to pursue this. In this light, the Commission's approach towards IUU fishing is based on the same constraints as any RFMO with high seas in its regulatory area.

\section{IUU Fishing}

The acronym IUU (illegal, unreported and unregulated) ${ }^{91}$ fishing captures problems faced by an increasing number of RFMOs. The acronym seems to have been used by the Commission since its 17th Meeting (1998), more or less simultaneously with its use in the 1998 Annual Meeting of the ICCAT Commission..$^{92}$ Awareness that IUU fishing avant la lettre was a serious problem within the CCAMLR Convention did not sufficiently crystallise until the 13th Commission Meeting (1994). ${ }^{93}$ At the global level, recognition of its seriousness led to calls for the development of an International Plan of Action (IPOA) on IUU Fishing within the framework of the FAO Code of Conduct. ${ }^{94}$ The IPOA was formally adopted at the 24th Session of COFI, on 2 March 2001. Three meetings held prior thereto were necessary to agree on its substance. ${ }^{95}$

88 Orrego Vicuña, note 73 above at pp. 120-122.

89 Cf. C.C. Joyner, "The Antarctic Treaty System and the Law of the Sea - Competing Regimes in the Southern Ocean", (1995) 10 International Journal of Marine and Coasial Law 301-331 at 307-311, who inter alia rejects the view that Art. VI of the Antarctic Treaty affects third states. Orrego Vicuña, note 73 above at p. 101 agrees.

90 E.g. B.H. Oxman, "Antarctica and the New Law of the Sea", (1986) 19 Cornell International Law Jounal 211247 at 223. Watts, note 7 above at pp. 295-298 expresses less support even though he does not exclude that an objective quality might attach to a part of the ATS

9] The individual components also appear as illegal, unregulated and unreported (e.g. ICCAT Resolution 99-11 (text at www.iccat.cs) and throughout Doc. CCAMLR-XVII).

92 See ICCAT Resolutions 98-18, 99-11 and 99-12 (tcxt at www.iccat.es). As early as 1994, ICCAT had already developed measures to deal with IUU fishing avant la lettre for bluefin tuna and has since then extended such measures to North Atlantic swordfish (e.g. ICCAT Recommendations 94-3, 94-6, 94-8, 94-9 and 97-8, text at www.iccat.es).

93 Cf. Herr, note 32 above, at section 3.

94 Code of Conduct for Responsible Fisheries (Rome, 31 October 1995; text at www.fao.org/fi), Art. 2(d). Australia has been instrumental in initiating this process, inter alia during the 23rd Session of COFI (1999) (see FAO Fisheries Report. No. 595, paras 72-73) and the 8th Session (2000) of the Subcommittee on Flag State Implementation (FSI) within the International Maritime Organisation (IMO) (see IMO Docs MSC. 72/7/4, MSC 72/23, paras 7.22-7.26 and 21.28, FSI 8/6, FSI 8/INF.6 and FSI 8/19, para. 6.14)

95 An Expert Consultation was held in Sydney in May 2000, a (First) Technical Consultation in Rome in October 2000, and a Second Technical Consultation also in Rome on 22-23 February 2001. At the time of writing, the Sydney Draft IPOA and the Rome Draft IPOA were available at or through www.fao.org/fi, whereas a copy of the IPOA had been provided to the author by W. Edeson (FAO). 
No global or regional instrument contains a definition of IUU fishing yet. While the IPOA on IUU Fishing also lacks a general definition, paragraphs 3.13.4 nevertheless offer definitions for the individual components. These definitions contain a range of nuances and imperfections that cannot be dealt with here. Something they nevertheless make clear is that IUU fishing can occur anywhere, including in coastal states' maritime zones, by both (co-operating) ${ }^{96}$ parties and non(co-operating)-parties to RFMOs and even in the absence of an RFMO. Moreover, the measures which states or RFMOs are ultimately recommended to take against IUU fishing do not distinguish between the three forms, even though one form may be more serious than another. ${ }^{97}$

Decisive for the distinction between "illegal" and "unregulated" fishing are the obligations to which a vessel's flag state is bound under international law. In general these international norms are not directed at vessels, but rather at the state in which these vessels are registered, namely the flag state. In discharging their obligation to exercise effective jurisdiction and control over ships flying their flag, flag states are responsible for activities of their vessels. ${ }^{98}$ Whether such activities can also lead to prosecutions depends on the domestic legal framework of the flag state or the state in whose jurisdiction the relevant behaviour took place. It is noteworthy that fishing activities by vessels not flying the flag of a state party to an RFMO would qualify as "unregulated" under paragraph 3.3.1 of the IPOA on IUU Fishing but may also be "illegal" pursuant to its paragraph 3.1.3. ${ }^{99}$ Finally, it is crucial for the opposability of measures taken by RFMOs in order to prevent, deter and eliminate IUU fishing, that the RFMO has been established in consistency with international law and that due regard is taken of the concept of real interest and of the need to provide equitable participatory rights to all. ${ }^{100}$

The significance of IUU fishing in the CCAMLR Convention Area can to some extent be deduced from catch statistics. IUU fishing is mainly or exclusively aimed at toothfish and not at the more important target species krill, at least as regards quantity. ${ }^{101}$ The total legal catch of finfish reported from the Convention Area for the 1999/2000 split-year was 19,283 tonnes, of which toothfish accounted for 14,440 tonnes. In the 1998/99 split-year this figure was

ICCAT also recognises "Cooperating Parties, Entities or Fishing Entities" (see ICCAT Resolutions 97-17 and 98-5, text at www.iccat.es).

97 Para. 3.4 of the IPOA has nevertheless been included as a safeguard.

98 See Art. 94 of the LOS Convention, Art. III of the 1993 FAO Compliance Agreement (Agreement to Promote Compliance with International Conservation and Management Measures by Fishing Vessels on the High Seas, Rome, 24 November 1993, not in force, (1994) 33 ILM 969; in April 2001, 20 acceptances were received (25 required)), Art. 18 of the 1995 Fish Stocks Agrcement and Art. 6.11 of the 1995 FAO Code of Conduct.

99 Herr, note 32 above, after note 54 observes that the fact that non-parties to the CCAMLR Convention comply with FAO reporting obligations enables IUU catch estimates to be made.

${ }^{100}$ See Molenaar. note 33 above.

${ }^{101}$ The total catch of krill reported from the Convention Area for the 1998/99 split-year was 103,318 tonnes, and 101,286 tonnes for the 1999/2000 split ycar. 
18,094 tonnes with 17,435 tonnes of toothfish, whereas the total reported legal catch in $1997 / 98$ was 11,419 tonnes. IUU catches of toothfish in the $1999 / 2000$ split-year were estimated to be 12,500 tonnes, compared to 10,733 tonnes in the $1998 / 99$ split-year, 33,583 tonnes in the $1997 / 98$ split-year, and 38,000-42,800 tonnes in 1996/97.102 These IUU estimates are not always reliable and much higher estimates for IUU catches have also been made. ${ }^{103}$

As was already noted above, (co-operating) parties to RFMOs may also be involved in IUU fishing. Their involvement may not only occur through vessels flying their flag, but also by (1) allowing their ports to be used for landings of IUU catches; (2) allowing IUU fish to be imported, processed, retailed or exported; or (3) allowing their nationals and companies to own or operate IUU vessels or otherwise be involved in trade or processing IUU fish. Singling out specific parties to the CCAMLR Convention without statistics in support, is of limited value. Nevertheless, allegations have been made that Norwegian and Spanish nationals and companies, Namibian and Uruguayan ports and Chilean and Japanese markets share considerable responsibility for IUU fishing in the CCAMLR Convention Area. ${ }^{104}$

At least as serious, however, is the role of various non-parties to RFMOs. Table 1 lists several states and the capacities in which they are involved in IUU fishing in the CCAMLR Convention Area. While free-riders "merely" share responsibility for over-fishing, commonly they do not share the costs and efforts of necessary conservation measures. This imposes a serious strain on the willingness of parties to RFMOs to agree on conservation measures. The situation in the CCAMLR Convention is in that respect no different than in other RFMOs and explains, at least in part, why NGOs' calls for a moratorium on toothfish were ignored at the 19th Commission Meeting (2000). Ultimately, however, this cannot always be a sufficient excuse for refraining from adopting appropriate measures, including even a moratorium. ${ }^{105}$ The issue of responsi-

102 Based on CCAMLR Newsletter No. 21, 1999, available at www.ccamlr.org; Doc. CCAMLRXIX, paras 4.7 and 5.2 (advance copy); and the press release of 3 November 2000 by ASOC, text at www asoc.org, visited at 29 November 2000.

103 CCAMLR Newsletter No. 19. 1997, still reported that about 130,000 tonnes of toothfish were believed to be available on the world market in 1997. This would be similar to the estimate of 100,000 tonnes, or more, of IUU toothfish for 1997 made by ISOFISH, note 2 above. The CDS referred to in note 12 above inter alia addresses this estimating difficulty. See also Agnew, note 3 above at p. 263.

104 Based on an ASOC press release of 23 October 2000, and issues of the ASOC newspaper, ECO, at www.asoc.org; ISOFISH Occasional Reports No. 2 and No. 3 (available at www.isofish. org.au): and Doc. CCAMLR-XIX, para. 5.36 (advance copy). See also Resolution 14/XIX, note 120 below.

${ }^{105}$ In their Joint Declaration in the Southern Bluefin Tuna cases before the ITLOS (New Zealand $\mathrm{v}$ Japan; Australia v Japan, Requests for Provisional Measures, Order of 27 August 1999, text at www.un.org/Depts/los), Vice-President Wolfrum and Judges Caminos, Marotta Rangel, Yankov, Anderson and Eiriksson argue that in light of the depleted and poor state of the stock, the ineffective co-operation among the state parties to the CCSBT Convention (note 34 
Table 1 Non-contracting parties to the CCAMLR Convention involved in IUU fishing for toothfish

\begin{tabular}{llll}
\hline State Flag state $\quad$ Market state Port state & $\begin{array}{l}\text { Owner/operator } \\
\text { home state }\end{array}$
\end{tabular}

\begin{tabular}{|c|c|c|c|c|}
\hline Belize & Yes & & Yes & \\
\hline Canada & & Yes $^{\mathrm{a}}$ & & \\
\hline China & & Yes $^{\mathrm{a} c}$ & & \\
\hline Denmark ${ }^{b}$ & Yes & & Yes & \\
\hline Honduras & Yes & & Yes & \\
\hline Malta & Yes & & Yes & \\
\hline Mauritius & Yes & & Yes & Yes \\
\hline Mozambique & & & Yes & \\
\hline Panama & Yes & & Yes & Yes \\
\hline Portugal $^{b}$ & Yes & & Yes & \\
\hline Sao Tomé & & & & \\
\hline and Principe & $\mathrm{Yes}^{\mathrm{c}}$ & & & \\
\hline Seychelles & Yes & & & Yes \\
\hline Singapore & & Yes & & \\
\hline Vanuatu & Yes & & Yes & \\
\hline
\end{tabular}

Notes:

a Based on the ASOC press release of 23 October 2000.

b As a Member State of the European Union. Portugal and Denmark are nevertheless subject to regulation. See the section entitled The Characterisation of the CCAMLR Convention and the Role of the EC" at pp. 490497 below.

c Based on Doc. CCAMLR-XIX, paras 16.3-16.4 (advance copy).

Source: ISOFISH website, www.isofish.org.au

bility must be subordinated to the international community's interest in the conservation of marine living resources and biological diversity.

In global terms, the annual aggregated catch in the CCAMLR Convention Area is not very significant; neither in quantity nor in value. However, as even the more conservative estimates of IUU catches are considerable when compared to legal catches, IUU fishing within the framework of the CCAMLR Convention is obviously a serious problem. Furthermore, IUU fishing is often in noncompliance with Conservation Measures and therefore responsible for a disproportionally negative impact on the ecosystem, for example a high

contd.

above) and the rising catches of non-parties, "a reduction in the catches of all those concerned in the fishery in the immediate short term would assist the stock to recover over the medium to the long term. Article 64 of the [LOS Convention] lays down, as stated in the Order, a duty to cooperate to that end." 
incidental bird mortality rate or potentially the introduction of alien species. ${ }^{106}$ Remedial action is also necessary for the more fundamental reason that disregard for regulatory efforts might spill over to other areas in the ATS or because the Antarctic is perceived as worthy of the highest level of efforts. ${ }^{107}$ Despite all this, IUU fishing is not the only source of problems for RFMOs, including the Commission, and simultaneous efforts are needed to address these.

In light of the different types of involvement in IUU fishing, only a comprehensive and integrated approach is likely to be successful. While this would be advisable for any RFMO and the IPOA on IUU Fishing is in fact based on this perception, it is particularly relevant in light of the challenges for the situation in the CCAMLR Convention Area. The special sovereignty situation, the vastness of the area, the extremely harsh weather and sea conditions, and the remoteness from "non-scientific" settlements, all have a profound impact on the related problems of compliance and enforcement.

Whereas both parties and non-parties to RFMOs are involved in IUU fishing, in searching for remedies it is often necessary to distinguish between the two. Efforts belonging within the sphere of the first approach (inter se), are essential for bolstering the credibility of RFMOs. In the context of the CCAMLR Convention, this is all the more evident in light of the fact that a lot of fishing activity in the CCAMLR Convention Area appears to be controlled by nationals and companies of state parties. ${ }^{108}$

One of the inter se efforts would be the strengthening of the CCAMLR System of Observation and Inspection. ${ }^{109}$ This already allows for boarding and inspection by designated inspectors that do not necessarily have the nationality of an inspected vessel's flag state. Consistent with the inter se approach, vessels flying the flag of non-parties to the CCAMLR Convention cannot be subjected

${ }^{106} \mathrm{Cf}$. Stone, note 16 above at pp. 95-96, who also mentions the impact of the dumping of fish on markets and potential risks to human life (e.g. by substandard vessels and resisting enforcement).

${ }^{107}$ See Resolution 3 (1999), "Support for CCAMLR", adopted at the XXIIIth ATCM (1999). Note that the Dissenting Opinions of Judge Anderson (under (c)(3) of "The Question of Compliance with Article 73(2)") and Judge Wolfrum (para. 17) in the Camouco case (Panama v France, Application for Prompt Releasc. Judgment of 7 February 2000, text at www.un.org/Depts/los) before the ITLOS, refer to IUU fishing and the situation under the CCAMLR Convention as considerations that are relcvant to the coastal state's discretion in setting "reasonable" bonds for prompt release. In the Monte Confirc $o$ case (note 31 above) this is also argued by France (see ITLOS/PV.00/6, p. 11) and by Judge Anderson in his Dissenting Opinion, whereas the ITLOS mercly took "note of this argument" (para. 79 of the Judgment).

${ }^{108}$ So far, the Commission has not been very active in this field. However, see Resolution 13/XIX discussed in the main text below. See also Art. XXI(1) of the CCAMLR Convention.

109 See the calls for such strengthening by ASOC in Doc. CCAMLR-XVI/BG/38. See also R. Rayfuse, "Enforcement of High Seas Fisheries Agreements: Observation and Inspection Under the Convention on the Conservation of Antarctic Marine Living Resources", (1998) 13 International Journal of Marine and Coastal Lav. 579-605 and, more generally, M. Hayashi, "Enforcement by Non-Flag States on the High Seas Under the 1995 Agreement on Straddling and Highly Migratory Fish Stocks", (1996) 9 Georgetown International Environmental Law Review' 1-36. 
to such enforcement measures. ${ }^{110}$ Other measures adopted by the Commission to improve compliance by vessels flying the flag of parties include: data reporting, ${ }^{11}$ licensing requirements, ${ }^{112}$ marking of fishing vessels and fishing gear, ${ }^{113}$ an automated satellite-linked Vessel Monitoring System (VMS), ${ }^{114}$ and a Catch Documentation Scheme (CDS) for toothfish. ${ }^{15}$ While these measures only apply to parties, some, such as the VMS and CDS, indirectly foster chances for improving compliance by non-parties. ${ }^{116}$ Recent initiatives for aerial and surface patrols complement these. ${ }^{117}$

Apart from these indirect effects, however, efforts to address involvement in IUU fishing by non-parties to RFMOs are commonly constrained by the consensual nature of international law as reflected in the principle of pacta tertiis. At the global level efforts should therefore be undertaken to enhance flag state performance and responsibility. This was in fact one of the main objectives behind the development of the 1993 FAO Compliance Agreement, ${ }^{118}$ the 1995 Fish Stocks Agreement and the 1995 FAO Code of Conduct. The fact that the first two of these have still not entered into force largely explains the initiative for the IPOA on IUU Fishing.

At the regional level, ways have to be found that do not overstep the limits set by the principle of pacta tertiis. This was already envisaged by Article $\mathrm{X}$ of the CCAMLR Convention, which charges the Commission with notifying non-party states of "any activity undertaken by its nationals or vessels which affects the implementation of the objective of this Convention". In a similar fashion, Article XXII firmly stipulates that: "Each Contracting Party undertakes to exert appropriate pressure, consistent with the Charter of the United Nations, to the end that no one engages in any activity contrary to the objective of this Convention."

110 Art. III, footnote 2 of the CCAMLR System of Inspection (text at www.ccamlr.org).

111 See, inter alia, CMs 51/XII, 121/XVI, 122/XVI and 51/XIX

112 CM 119/XVII, "Licensing and Inspection Obligations of Contracting Parties with Regard to Their Flag Vessels Operating in the Convention Area", in addition to Art. IV(c) of the CCAMLR System of Inspection.

113 CM 146/XVII.

114 CM 148/XVII. See also Resolution 16/XIX and the section on CCAMLR in E.J. Molenaar and M. Tsamenyi, "Satellite-Based Vessel Monitoring Systems (VMSs) for Fisheries Management International Legal Aspects and Developments in State Practice" (FAO Legal Papers Online \#7), available at www.fao.org/legal.

$115 \mathrm{CM}$ 170/XIX, with Annex 170/A and Explanatory Memorandum. It is noteworthy that state parties "shall take steps to identify the origin of" toothfish (para. 1), which implies that, where catch is taken outside the CCAMLR Convention Area, the catch document shall indicate the appropriate FAO statistical area, subarea or division (para. 6(iv)(b)). The Chairman's Statement has not been invoked, which implies that the Catch Documentation Scheme also applies within maritime zones of undisputed territory within the CCAMLR Convention Area.

116 See Agnew, note 3 above, who concludes on p. 370 that the CDS is consistent with GATT. Kaye, note 7 above at pp. 441-442, sees more problems.

117 Australia, France, New Zealand, South Africa and the United Kingdom are undertaking such patrols. See inter alia note 106 above for the ensuing ITLOS cases.

${ }^{118}$ See note 98 above. 
As a logical first step, the Commission routinely invites non-parties involved in IUU fishing to attend Commission Meetings as observers, to accede to the Convention and/or become a member of the Commission. ${ }^{119}$ A related and complementary approach is to invite non-parties to participate in relation to specific Conservation Measures. ${ }^{120}$ At the 18th Commission Meeting (1999) a more comprehensive approach to achieving voluntary compliance was adopted through the "Policy to Enhance Cooperation between CCAMLR and NonContracting Parties" (CCAMLR NCP Policy). ${ }^{121}$ This Policy, which is directly linked to IUU fishing and the CDS adopted at the same meeting, contains a wide range of requests to non-contracting parties. These requests include invitations to attend Commission Meetings as observers or accede to the Convention, providing information on IUU fishing by their flag vessels (including by in-port inspections), and to deny landing or transhipments in their ports of fish not harvested in compliance with Conservation Measures or the CCAMLR Convention. ${ }^{122}$ In addition, paragraph III stipulates that: "Parties shall individually and collectively take all appropriate efforts to implement or assist in the implementation of this policy; such efforts may include taking concerted action on joint demarches on non-Contracting Parties to complement correspondence from the Chairman." 123

Unfortunately, past experience in marine capture fisheries management has shown that unrelenting deference for the primacy of flag state jurisdiction and reliance on voluntary compliance has not been fruitful. The CCAMLR Convention is not an exception. While observing the pacta tertiis principle, ways therefore have to be found to exert pressure. The 17th Commission Meeting (1998) led to the adoption of Conservation Measure 118/XVII, entitled "Scheme to Promote Compliance by Non-Contracting Party Vessels with CCAMLR Conservation Measures" (CCAMLR NCP Scheme). The CCAMLR NCP Scheme contains a variety of measures aimed at bolstering compliance by non-parties, including the prohibition on receiving transhipments from ships involved in IUU fishing, transmission of information on sightings of fishing or transhipments (inter alia to facilitate port state control), compulsory in-port inspection, and the prohibition of landings and transhipments in port "unless the vessel establishes that the fish were caught outside the Convention Area or in compliance with all relevant CCAMLR Conservation Measures and require-

${ }^{119}$ These invitations are very often ignored.

${ }^{120}$ E.g. the CDS (CM 170/XIX, nole 115 above), Preamble and para. 5. Resolution 14/XIX is explicitly aimed at the implementation of the CDS by "Acceding States and Non-Contracting Parties". See also Resolution 16/XIX.

121 Including Attachment A, entitled "Submission of Information by Non-Contracting Parties on Landings and Transhipments of Toothfish (Dissostichus spp.) in Their Ports" (text at www.ccamlr.org, under "Catch Documentation Scheme").

122 An Australian draft even provided for requesting denial of non-emergency access to ports, but this aspect was not adopted (Doc. CCAMLR-XVIII/BG/51, para. 2(i)).

123. This effectively codifies existing practice. 
ments under the Convention". So far, however, not many port state inspections seem to have been carried out. ${ }^{124}$

At the 19th Commission Meeting (2000) several interesting developments took place which further increase pressure on non-parties. First, Conservation Measure $147 /$ XIX was revised once again ${ }^{125}$ by including wording to require vessels prior to entry into port "to convey a written declaration that they have not engaged in or supported" IUU fishing in the CCAMLR Convention Area. Consequently, "Vessels which either declare that they have been involved in IUU fishing or fail to make a declaration shall be denied port access." If in-port inspections nevertheless reveal involvement in IUU fishing, those responsible risk being charged with making a false statement. ${ }^{126}$ Secondly, Resolution 15/ XIX urges parties to discourage their flag vessels from using the ports of those acceding states or non-parties that are not implementing the CDS, unless an authorised flag state official monitors landings. ${ }^{127}$ Thirdly, Resolution 13/XIX urges:

"all Contracting Parties, consistent with their domestic legislation, to avoid flagging a non-Contracting Party vessel or licensing such a vessel to fish in waters under their fisheries jurisdiction, if that particular vessel has a history of engagement in IUU fishing in the Convention Area."

Fourthly, Brazil made an official statement that it would not utilize chartered vessels for fishing allocations in the CCAMLR Convention Area. ${ }^{128}$

These new developments raise a number of questions that cannot all be dealt with here. It is worth observing that the first three developments all have an aspect of "blacklisting". ${ }^{29}$ Moreover, Resolution 13/XIX does not explicitly apply to vessels of parties even though certain states already have a practice of refusing licences to domestic vessels. One of these is Norway, who in fact submitted the proposal culminating in Resolution 13/XIX in 1999. It is noteworthy that a somewhat similar approach was incorporated in the Sydney Draft IPOA, removed from the Rome Draft, but finally inserted elsewhere in the IPOA on IUU Fishing. ${ }^{130}$ In addition, the newly inserted wording in Conservation Measure 147/XIX is similar to paragraph 45 of the Sydney Draft IPOA, but this was not retained in that form in the IPOA. Both examples

124 Agnew, note 3 above at p. 367.

125 It had already been aligned with CM 118/XVII.

126 South Africa already used this method.

127 Resolutions are non-legally binding (see note 15 above).

128 Doc. CCAMLR-XIX, para. 7.18 (advance copy).

129 Para. 4 of CM 147/XIX obliges parties to advise the CCAMLR Secretariat of "any vessels denied port access or permission to land or tranship" toothfish and to forward this information to other parties.

130 Para. 28 of the Rome Draft and para. 51.8 of the IPOA. New Zealand already applies this approach in practice, c.g. in relation to orange roughy on the Challenger Platcau (see Molenaar, note 33 above). 
illustrate that the Commission is able to take a more proactive and progressive stance than would be possible at the global level. ${ }^{131}$ Finally, the Brazilian statement is remarkable for a number of reasons but especially because it appears restricted to the context of the CCAMLR Convention. ${ }^{132}$

In conclusion, it is submitted that the CCAMLR NCP Policy and Scheme treat the dilemma of non-parties in a way that is sanctioned by international law. One of its key elements, port state control, is consistent with Article 23 of the 1995 Fish Stocks Agreement inter alia in light of the fact that it is agreed multilaterally and not affected by the crucial issues of participation and allocation. ${ }^{133}$ There is currently no clear intention for the CCAMLR Convention to avail itself of the non-flag state powers under Articles 21 and 22 of the 1995 Fish Stocks Agreement, should that come into force. A preliminary issue would at any rate be the characterisation of the CCAMLR Convention, something that is addressed in the next section.

\section{The Characterisation of the CCAMLR Convention and the Role of the EC}

At the 18th Commission Meeting (1999), the EC issued a notification, on behalf of the Portuguese vessel Lugalpesca, to engage in an exploratory fishery for Patagonian toothfish in the $1999 / 2000$ season. ${ }^{134}$ Its salient element was that Portugal was then not a state party to the CCAMLR Convention; nor is it now. However, Portuguese vessels had already been engaged in fishing in the CCAMLR Convention Area for several years. ${ }^{135}$ The EC notification thus raises questions on two related issues: (1) the distribution of fisheries competence between the EC and its Member States; and (2) the characterisation of the CCAMLR Convention.

With respect to the first question, it is widely known that by way of the Common Fisheries Policy, EU Member States have transferred a very large measure of their fisheries competence to the EC. ${ }^{136}$ However, the EC declaration

131 See Doc. CCAMLR-XIX, paras 5.40-5.45 (advance copy), indicating that the proposal was not without controversy.

${ }^{132}$ See also para. 37 of the IPOA on IUU Fishing; and Molenaar, note 12 above, especially the section on "Flag State Responsibilities."

${ }^{133}$ See note 100 above and the accompanying text. It is worth observing that at the 19th Commission Meeting (2000). New Zealand threatened to use port state jurisdiction if its preferred conservation approach for the Ross Sea (Statistical Subarea 88.1) was not adopted (see Doc. CCAMLR-XIX, para. 2.5 (advance copy) and also paras 7.1, 7.15, 9.49 and 9.56 9.59).

134 Doc. CCAMLR-XVIII/21. The original notification of 29 September 1999 (attached to Doc. CCAMLR-XVIII/21) still spoke of "a notification by Portugal, in its capacity as a member of the $[\mathrm{EC}] "$ ".

135 Kaye, note 25 above, refers to Doc. CCAMLR-XV.pp. 25-26 and 141 where Portuguese fishing activity was observed in 1996.

${ }^{136}$ See Arts 3(1)(e), 32, 33 and 37 of the EC Treaty (consolidated version; Treaty Establishing the European Economic Community, Rome, 25 March 1957, in force 1 January 1958, text at 
accompanying its instrument of formal confirmation of the LOS Convention ${ }^{137}$ clearly reflects that this competence is not exclusive for all purposes. The caption "Matters for which the Community has exclusive competence" is immediately followed by the words:

"The Community points out that its Member States have transferred
competence to it with regard to the conservation and management of sea
fishing resources. Hence in this field it is for the Community to adopt the
relevant rules and regulations (which are enforced by the Member States)
and, within its competence, to enter into external undertakings with third
States or competent international organisations. This competence applies
to waters under national fisheries jurisdiction and to the high seas.
Nevertheless, in respect of measures relating to the exercise of jurisdiction
over vessels, flagging and registration of vessels and the enforcement of
penal and administrative sanctions, competence rests with the Member
States while respecting Community law. Community law also provides for
administrative sanctions." 138

This reflects a delicate balance of competence which would also be typical for many federal states and which is expected to be in a constant state of flux. This is inter alia reflected in the differences between the above-mentioned declaration for the LOS Convention and other declarations ${ }^{139}$ and specific disagreements on the distribution of competence, for instance in relation to the $1993 \mathrm{FAO}$ Compliance Agreement and the 1995 Fish Stocks Agreement. ${ }^{140}$ As a rule of thumb it could be said that prescriptive powers are vested with the EC while enforcement is mainly a matter for the Member States. ${ }^{141}$ An important

cont.

europc.cu.int/eur-lex; the EC Treaty has, inter alia, becn amended by the 1986 Single European Act, the 1992 Maastricht Treaty and the 1997 Amsterdam Treaty). The external competence of the EC in the sphere of fisheries rests mainly on its implied treaty-making powers (but see Art. 133 of the EC Treaty; see also R.R. Churchill, "The European Community and Its Role in Some Issucs of International Fisheries Law" in E. Hey (cd.), Developments in International Fisheries Law (The Haguc, Kluwer Law International, 1999), pp. 533-573 at pp. 536-537).

137 See note 74 above. The specific provision meant here is Art. 5(1) of Annex IX to the LOS Convention.

138 Full tcxt at www.un.org/Depts/los.

139 See inter alia paras 5-7 of the EC declaration upon signature of the 1995 Fish Stocks Agreement (text at www.un.org/Depts/los).

140 See Churchill, note 136 above at pp. 538-540 and 556-558. The 1993 FAO Compliance Agreement has finally been accepted by the EC, while the 1995 Fish Stocks Agreement will be ratified in concert by the EU Member States (Italy and Luxembourg were apparently unaware of that decision).

$141 \mathrm{Cf}$. Churchill, note 136 above at p. 540. The primary responsibility of the Member States for enforcement is formally sanctioned by Council Regulation (EEC) No. 2847/93 of 12 October 1993, consolidated text at curope.eu.int/eur-lex. 
exception to this general rule is that this transfer of competence does not apply with respect to certain territories of the Member States. ${ }^{142}$

Despite the fact that RFMOs are often also active in relation to enforcement, as a general rule EU Member States are in principle no longer allowed to be a party to RFMOs in situations that do not involve the above-mentioned territories. ${ }^{143}$ The EC Commission represents the EC, through its Fisheries Directorate-General (DG). ${ }^{144}$ Experts from Member States may nevertheless accompany the EC Commission to meetings of RFMOs, and co-ordination meetings between the EC Commission and EU Member States are held during or prior thereto, in order to agree on a "common position". Decisions taken by RFMOs that are binding upon the EC will be transposed into EC law. Ultimately, therefore, such decisions will become binding for all EU Member States.

This common situation exists in IBSFC (International Baltic Sea Fishery Commission), ICCAT, IOTC, NAFO (Northwest Atlantic Fisheries Organization), NASCO (North Atlantic Salmon Conservation Organization), NEAFC (NorthEast Atlantic Fisheries Commission) and, upon its entry into force, under the SEAFO Convention. ${ }^{145}$ The prospective SWIOFC Agreement could be added thereto as the EC already represents the EU Member States (apart from those with relevant territories) in this negotiation. ${ }^{146}$ The recently adopted Honolulu Convention can be grouped together with these as well, even though the EC may experience difficulties in acceding. ${ }^{147}$ Similarly, the Galapagos Agreement would allow the EC to accede, even though it was never invited to participate in its negotiation and provided it satisfies several questionable requirements. ${ }^{148}$

Certain RFMOs, however, have not (yet) honoured the wish of the EC to become a party. This concerns WECAFC (Western Central Atlantic Fishery Commission) and IATTC (Inter-American Tropical Tuna Commission), even

142 See Part Six, Art. 299 and Annex II to the EC Treaty (note 138 above). See also R.R. Churchill, EEC Fisheries Law' (Dordrecht. Boston and Lancaster, Martinus Nijhoff Publishers, 1987), pp. 55-57 (regardless of the nced for updating). Note that the fisheries competence of France and the United Kingdom under the CCAMLR Convention rests on this construction.

143 See in general COM (1999) 613 final, "Community Participation in Regional Fisheries Organisations (RFOs)", text at europa.cu.int/comm/fisheries/doc_et_publ/factsheets/legal_texts/comm_en.htm.

144 Cf. Art. 300 of the EC Treaty, note 138 above.

145 Notc 38 above, Art. 25

146 Note 39 above, draft Art. IV(a)(iii) and para. 2 of the Report of the First Intergovernmental Consultation.

${ }^{147}$ See note 36 above. See also Art. 35(2) of the Honolulu Convention and Molenaar, note 12 above, in particular pp. 509-514 on the MHLC process.

${ }^{148}$ See note 37 above. Sce Arts 1(1.3), 1(1.4), 1(1.6) and 16(2) of the Galapagos Agreement and Molenaar, note 33 above, in the section on port state jurisdiction. Discontent with references to the Honolulu Convention and the Galapagos Agreement in UN General Assembly Resolution A/RES/55/8 (2000). Preamble, apparently made the EC call for a vote on this resolution, which is usually adopted by consensus. Note also that the Galapagos is mentioned in a separate paragraph from the one referring to the SEAFO and Honolulu Conventions. 
though developments are under way that might change this. ${ }^{149}$ Whereas states that already participate in such RFMOs may prevent the EC from formally exercising its competence, this does not have real implications on the distribution of competence between the EC and EU Member States. The above-mentioned co-ordination meetings see to that.

In yet another group of RFMOs, EU Member States are parties alongside the $\mathrm{EC}$, even though these states do not (all) possess relevant territories. This group includes the CCAMLR Convention together with CECAF (Fishery Committee for the Eastern Central Atlantic) and GFCM (General Fisheries Commission for the Mediterranean). The potential implications of the EC notification on behalf of Portugal, a non-party to the CCAMLR Convention, were therefore considerable. It could be the EC's first step towards a role which it enjoys in RFMOs of the first group referred to above. In justifying its notification, the EC mentioned the transfer of competence by EU Member States to the EC and the already mentioned consequences when RFMOs adopt measures that are binding upon the EC and thereby implicitly upon EU Member States. The matter sparked considerable controversy and not just among non-EU Member States. Whereas the relatively simple, and consequently one-sided, description of the distribution of competence between the EC and EU Member States may have played a minor role, ${ }^{150}$ the more fundamental issue was whether the usual distribution of competence in fisheries was in fact applicable in the case of the CCAMLR Convention.

The EC notification on behalf of Portugal ${ }^{151}$ finally managed to secure consensus during the very last moments of the Meeting. ${ }^{152}$ Nevertheless, "the majority of the members of the Commission took the position that any fishing by a Portuguese-flagged vessel would be in contravention of the Convention unless Portugal had acceded to the Convention prior to the initiation of such activities" and "[t]he Commission called upon Portugal to consider favourably early accession to the Convention". ${ }^{153}$ Subsequently, Argentina, Australia and New Zealand reserved their "rights under the Convention" whereas Chile, the

${ }^{149}$ See also the situation in the IWC in the main text below. The status of WECAFC may be altered from an Art. VI into an Art. XIV body under the FAO Constitution (text of the Constitution at www.fao.org/legal; see FAO Doc. WECAFC/IX/99/5E (text at www.fao.org/fi/meetings/ wecafc/1999), para. 33). The EC currently participates as observer in IATTC. During the 63rd IATTC Meeting (1999), a Protocol to the 1949 IATTC Convention was adopted (Protocol to Amend the 1949 Convention on the Establishment of an Inter-American Tropical Tuna Commission, Guayaquil, 10 June 1999. not in force, text available at www.iattc.org), which allows the EC to accede to the IATTC Convention (adopted at Washington DC, 31 May 1949, in force 3 March 1950, text at www.iattc.org). As at 12 April 2001 none of the required 12 ratifications had been deposited.

${ }^{150}$ Sec Doc. CCAMLR-XVIII, para. 9.42.

151 Doc. CCAMLR-XVIII consistently uses "European Community (Portugucse-flagged)" in relation to the exploratory longline fishery for toothfish (paras 9.36 9.41)

152 This was only possible after relentless negotiation pressure by the EC.

153 Doc. CCAMLR-XVIII, paras 9.44 and 9.46 . 
Russian Federation and South Africa went as far as associating themselves with the views of the former. ${ }^{154}$

Almost three months after the Meeting, on 21 January 2000, the EC informed the Executive Secretary of the Commission that, due to technical reasons, the implementation of the EC's exploratory fisheries project involving the vessel Lugalpesca was suspended. It is not unlikely that pressure exerted not only by third states but also by EU Member States made the EC Commission realise its approach was not the most appropriate. However, in its communication, the EC observed that, should the technical problems be overcome, the EC will notify the Commission sufficiently in advance. ${ }^{155}$ At the time of writing this had not yet been done.

The latest development took place at the 19th Commission Meeting (2000), where the EC re-emphasised the distribution of competence between the EC and its Member States and requested "that, in addition to the requirements under the Rules of Procedure, any communications with regard to fishing matters in respect of its Member States should be sent to the [EC]". As Australia and other members of the Commission "noted that this suggestion was contrary to Rule 38 of the Rules of Procedure which required all communications to be sent to all Members [of the Commission]", this request was denied. ${ }^{156}$

It was already mentioned at the outset of this section that the distribution of competence between the EC and its Member States and the characterisation of the CCAMLR Convention are strongly related issues. Some of the reasons why non-EU Member States would be opposed to an "EC notification on behalf" have nevertheless little to do with the special character of the CCAMLR Convention. First, as EU Member States retain a considerable measure of competence in enforcement matters, other states could be concerned that not being a party to the CCAMLR Convention might negatively affect compliance. This sentiment stems from distrust of the EC (Commission)'s ability to ensure compliance. Secondly, there may be a concern that EU Member States are shielded from dispute settlement procedures that would normally apply to parties to the CCAMLR Convention. Thirdly, the EC approach would imply that EU Member States like Portugal would be exempt from paying contribution

${ }^{154}$ Thid., paras 9.47-9.52. Presumably, Argentina, Australia and New Zealand thus invoked their right to opt out under Art. IX(6)(c) of the CCAMLR Convention. See also the section entitled "Objective and Institutional Bodies" at pp. 467-470 above.

155 The EC Communication has been included in Doc. CCAMLR COMM CIRC 00/02. In a communication of 4 February 2000 to the Executive Secretary of CCAMLR, New Zealand reaffirms that it reserves its rights under the Convention in relation to the CMs relevant to the EC notification but also notes that the matter has now been resolved by this latest EC Communication of 27 January 2000.

156 Doc. CCAMLR-XIX, para. 17.1 (advance copy). In the context of the replacement of the Executive Secretary to the Commission, it has also been asserted that this should be a national of a state party of the CCAMLR Convention. As would be expected, the EC Commission appears to have objected as a matter of principle. 
as a member of the Commission, and this may be perceived as unfair. Other EU Member States might in fact be tempted to end their membership of the Commission. Potential implications for allocation do not appear to play a role. ${ }^{157}$ The first two concerns in particular are not unique for the CCAMLR Convention but exist in other RFMOs as well. Occasionally, such concerns may have been responsible for opposition when the EC intended to replace its Member States. ${ }^{158}$ While this is not necessarily true for the case of the CCAMLR Convention, to some extent such opposition may also be a divide-and-rule strategy against the EC and its Member States.

Two other arguments concern more specifically the special character of the CCAMLR Convention. First, the CCAMLR Convention is firmly embedded in the ATS through a number of linkages, including the crucial sovereignty status of Antarctica. Accession to the CCAMLR Convention involves a great deal more than acceding to a "standard" RFMO. Some claimant states have undoubtedly interpreted the "EC notification on behalf" as a failure to treat the CCAMLR Convention as an integral part of the ATS and as insufficient respect, or even recognition, for the crucial agreement to disagree on the sovereignty issue. ${ }^{159}$

The second reason is the conservationist character of the CCAMLR Convention, which is not merely concerned with fisheries but with "Antarctic marine living resources", including therefore birds and marine mammals. Consequently, Churchill concludes it is a mixed agreement for which the EC does not have exclusive competence. ${ }^{160}$ From that perspective, the situation under the IWC Convention is somewhat similar. The IWC Convention allows only governments as parties ${ }^{161}$ and the EC currently participates merely as an observer. In 1979, however, the EC Commission made an internal proposal for the EC to become a party to the IWC Convention and replace EU (EEC) Member States. This proposal did not secure enough support at EC Council meetings held in 1979 and 1980, mainly because some Member States contested the Community's competence in matters of whaling. ${ }^{162}$ Interestingly, the EC delegation to the CCAMLR Commission has always consisted of personnel of DG Fisheries without representation of DG Environment. At least in recent years, this has been the same in the IWC Commission. While there are probably a number of reasons for arguing that this does not necessarily reflect a

${ }^{157}$ See the section entitled "Objective and Institutional Bodies" at pp. 467-470 above. A formal argument would be that the CCAMLR Convention does not allow an allocation to a non-party, like e.g. ICCAT does.

${ }^{158}$ Churchill, note 141 above at pp. 544-545 describes difficulties in IBSFC, ICCAT, NAFO and NEAFC. The problems in IATTC still exist (see note 149 above).

159 Note that Art. XIII of the Antarctic Treaty does not allow the EC to become a party.

${ }^{160}$ Churchill, note 142 above at p. 189.

161 Art. X of the IWC Convention, note 52 above.

162 Churchill, note 142 above at p. 190. It is unclear if other reasons played a role as well. 
fundamental division of competence, there is likewise potential for change in the composition of these delegations.

Some may argue that the distinction between the CCAMLR Convention and other RFMOs is only subtle. The ecosystem approach is indeed incorporated in Article 5(d) of the 1995 Fish Stocks Agreement and is expected to lead to progressively wider implementation. For instance, IATTC has already developed the Agreement on the International Dolphin Conservation Program. ${ }^{163}$ Still, the very fact that the Commission is charged with the conservation of all "Antarctic marine living resources", including therefore in principle marine mammals such as whales, makes it clearly distinct from "regular" RFMOs.

This controversy on the role of the EC indicates that the CCAMLR Convention is not a "typical" RFMO. States acceding to the CCAMLR Convention should always be fully aware of this. At the same time, it does not necessarily exclude that the CCAMLR Convention qualifies as an RFMO for the purpose of the 1995 Fish Stocks Agreement. Among other things, this would bring the non-flag state powers under Articles 21 and 22 into view. ${ }^{164}$ As was shown in the previous section, the Commission's approach on IUU fishing is essentially similar to that of many other RFMOs even though it is one of the most progressive, comprehensive and integrated approaches.

As a preliminary issue, the fisheries managed by the Commission occur in various EEZs, even apart from those adjacent to Antarctica, and in an area beyond or adjacent thereto, whether or not this area constitutes high seas. This makes them "straddling" in the sense of Article 63(2) of the LOS Convention and, as a corollary, covered by the 1995 Fish Stocks Agreement. Although the Agreement does not contain a definition of an RFMO, this can be inferred from the definitions of "conservation and management measures" and "arrangement" in Article 1(1)(b) and (d) of the Agreement. In our context, the linchpin of such an inferred definition would be the words "for the purpose, inter alia" in Article 1(1)(d). Provided all other conditions are met, an RFMO could certainly have other purposes besides establishing conservation and management measures etc. As there is no indication to doubt that the CCAMLR Convention meets these other conditions, the CCAMLR Convention qualifies as an RFMO in the sense of the 1995 Fish Stocks Agreement. ${ }^{165}$

163 Washington DC, 21 May 1998, in force 15 February 1999, text at www.iattc.org.

164 Another highly relevant question concerns the rclationship between the dispute settlement provisions in the CCAMLR Convention (Art. XXV and Annex) and those in Part VIII of the 1995 Fish Stocks Agreement and Part XV of the LOS Convention.

${ }^{165}$ Herr, note 32 above, around note 66 , describes the discussions on this issue at the 14th Commission Meeting (1995). There Argentina argued that the CCAMLR Convention was merely a conservation instrument whereas most other members of the Commission accepted that the CCAMLR Convention "was a conservation body but that this was a broader inclusive term which incorporated its fisheries management responsibilities rather than an exclusive parallel that denied management activities". Argentina seems to have relied heavily on para. (1) of Art. II of the CCAMLR Convention. Watts, note 7 above at p. 219 submits that the CCAMLR 
Mention could here again be made of the legal status of the waters in the CCAMLR Convention Area. It was already concluded above that so far the Commission has not pursued erga omnes approaches based on the special sovereignty situation. This situation could nevertheless be invoked as a justification for utilising the tools of the 1995 Fish Stocks Agreement to address IUU fishing. As these calls for erga omnes approaches seem to a large extent based on a perceived legitimacy to act as custodian on behalf of the international community's interests, this offers another argument for treating the CCAMLR Convention as an RFMO. This relies on the view that developments in fisheries conservation and management in the last decade have increasingly charged RFMOs with a similar type of legitimacy.

\section{Conclusions}

As one of the instruments of the Antarctic Treaty System (ATS), the CCAMLR Convention is the main cornerstone in the regulatory framework for the conservation and management of marine living resources in the Southern Ocean. Its provisions and more than 20 years of implementation and application take due account of the shared and complementary competence of states and intergovernmental organisations, both substantively and geographically, and both within and adjacent to the CCAMLR Convention Area. This jurisdictional fragmentation is a direct consequence of the piecemeal evolution of regulatory regimes. Even the unique boundary of the CCAMLR Convention Area - based on the Antarctic Convergence - does not constitute a true boundary between certain target species within the competence of the Commission for the Conservation of Antarctic Marine Living Resources (the Commission) and those managed by other regional fisheries management organisations (RFMOs).

Although this situation does not appear fundamentally different from other regions in the world, for a number of reasons the CCAMLR Convention is an extraordinary regulatory regime that is quite distinct from (other) RFMOs. Its conservationist objective as reflected by the adherence to multi-species management and the ecosystem and precautionary approaches as well as the conditions for participation in the Commission, make it a particularly progressive instrument. Even though not yet fully realised, these ambitious goals are an inspiration for other RFMOs. Furthermore, the legal status of the waters in the CCAMLR Convention Area is special due to the Antarctic territorial claims. The factual characteristics of the CCAMLR Convention Area are also exceptional: the extreme sea and weather conditions, the vastness of the area and the remoteness from "non-scientific" settlements.

A legitimate question to ask would be whether the CCAMLR Convention has

cont.

Convention "creates what is almost wholly an international institutional resource management regime". 
been a success. In particular, has it been able to stop the typical "boom and bust" cycle in the exploitation of the Southern Ocean's marine living resources or can it be expected to do so in the future? In view of the many difficulties in assessing performance or effectiveness, especially from a legal perspective, all that can be offered here is some general observations.

Multi-species and ecosystem management are worthy objectives but extremely difficult to apply in practice, especially in such a vast and relatively unknown region of the world. The precautionary approach was in fact progressively adhered to as a consequence of this lack of information. IUU fishing is problematic for all RFMOs but especially so for the CCAMLR Convention due to its special jurisdictional and factual characteristics. While its response may have been somewhat late, in recent years the Commission has adopted a comprehensive and integrated approach to combat IUU fishing. This is paralleled by few RFMOs, if any, and constitutes a notable contrast with the relatively weak IPOA on IUU Fishing. As both parties and non-parties to the CCAMLR Convention are responsible for IUU fishing, the Conservation Measures, Policies and Resolutions adopted by the Commission reflect this duality. The increased and harmonised use of port state jurisdiction stands out as one of the non-voluntary measures primarily aimed at non-parties. All measures remain within the limits set by international law, inter alia due to the Commission's correct treatment of the sensitive issues of allocation and participation.

Improvements are of course always possible. With respect to IUU fishing, for instance, improvements could be achieved by further refinement of the Catch Documentation Scheme, introduction of trade measures, jurisdiction under the nationality principle and more (joint) efforts on monitoring, control and surveillance. Obviously, IUU fishing is not the only challenge, and reforms are welcome in other fields as well, for example on the system of competitive TACs. ${ }^{166}$ Calls may also again be made to improve compatibility between management in maritime zones off sub-Antarctic islands and the rest of the CCAMLR Convention Area. Sovereignty, sovereign rights and jurisdiction in maritime zones off undisputed sub-Antarctic islands are recognised by Article IV(2)(b) and (c) of the CCAMLR Convention and the Chairman's Statement. This situation is therefore essentially similar to that in RFMOs dealing with straddling or highly migratory fish stocks. Considerable restraint in invoking the Chairman's Statement already exists but could of course be reinforced.

The implications of the agreement to disagree on the sovereignty of Antarctica as regards the status of certain waters adjacent to Antarctica are a given and not likely to change. So far, the Commission does not claim custodianship to exercise collective rights erga omnes in the international community's interest in the

166 Although this will make the participation issue more difficult. 
sustainable management and conservation of the Antarctic living resources. As neither the Commission nor any other body within the ATS has indicated that this will change in the immediate future, the Commission's approach towards IUU fishing will experience the same constraints as RFMOs with high seas in their regulatory area.

In light of all these observations and the special features of the CCAMLR Convention, there is no immediate sign that the CCAMLR regime is less effective in comparison with other RFMOs. ${ }^{167}$ In that light it will be interesting to see whether upon entry into force of the 1995 Fish Stocks Agreement, steps will be taken to use the non-flag state powers under Articles 21 and 22 of the Agreement. This article has examined this through the related issues of (1) the distribution of competence between the EC and its Member States and (2) the categorisation of the CCAMLR Convention. It is submitted that the CCAMLR Convention is unlike other RFMOs due to the sensitive sovereignty dimension but also its broad conservationist objective. This is supported by the events following the unusual EC notification on behalf of a Portuguese vessel at the 18th Commission Meeting (1999), when Portugal was not party to any of the ATS instruments. Heated debate and protests did not prevent the EC notification from being accepted but a few months later the EC Commission declared it would not proceed with its intentions until further notice. This supports the argument that the CCAMLR Convention is a mixed agreement for which the EC and its Member States share competence. Unlike in many other RFMOs, EU Member States will therefore continue to be members of the Commission alongside the EC, even though they may not have relevant territories.

While the CCAMLR Convention is unlike other RFMOs, this does not prevent it from being categorised as "something more" than an RFMO. Article 1(1)(d) of the 1995 Fish Stocks Agreement does not rule out that an RFMO would have other purposes besides fisheries conservation and management. Even though not really necessary, the special sovereignty situation and factual characteristics of the CCAMLR Convention can be used to justify the use of the non-flag state powers under Articles 21 and 22 in the interests of the international community.

${ }^{167}$ See the balanced assessment by Gulland, note 63 above at pp. 234-238, who is not unfavourable towards the CCAMLR regime. Kaye, note 7 above at pp. 399-442 and Stokke, note 62 above, are also positive. 